\title{
Årsartikkel om lovendringer, lovforslag og stønader
}

\section{Det åttende blå statsbudsjettet etter stortingskompromisser - lovvedtak, stønader og lovforslag framsatt, vedtatt eller i kraft fra 2020}

\author{
Aslak Syse \\ Aslak Syse er cand.med. (1972), cand.jur. (1988) og dr. juris (1996). Fra 1989 har han vært \\ tilknyttet Institutt for offentlig rett ved Universitetet i Oslo, i tidsrommet 1997-2016 som \\ professor, fra 2017 som emeritus samme sted. \\ aslak.syse@jus.uio.no
}

\begin{abstract}
Sammendrag:
I artikkelen gjøres - som i tidligere år - rede for det vedtatte statsbudsjettet for 2021 på rettsområdene til $F A B$, samtidig som vedtakene ses i sammenheng med de budsjettforhandlingene som fant sted på Stortinget mellom trepartiregjeringen Solberg og Fremskrittspartiet.
\end{abstract}

Videre presenteres vedtatte lover og lovendringer fra 2020 innenfor FABs interessefelt.

For lesere som ikke ønsker en oversikt, men kun kjennskap til konkrete vedtak eller særskilte rettsområder, er det utarbeidet en detaljert innholdsfortegnelse.

\section{Nøkkelord:}

statsbudsjettet 2021, trygdestønader, lovforslag, velferdsrett, familierett, barnerett

1. Innledning 2

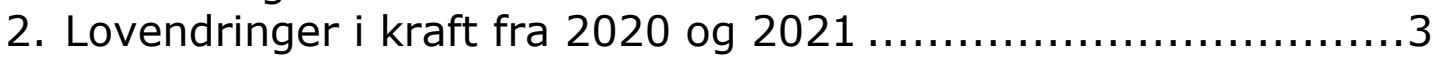

2.1 Innledning 3

2.2 Endringer i trygde- og pensjonsordninger.....

2.2.1 Trygdeskandalen og oppfølging av denne............................................. 4

2.2.2 Økte krav til bosted og opphold i Norge .................................................. 4

2.2.3 Nye regler for etterlatteytelser til ektefeller, tidligere familiepleiere og barn ............ 5

2.2.4 Store endringer for personer med flyktningstatus - supplerende stønad ................5

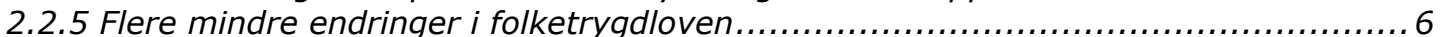

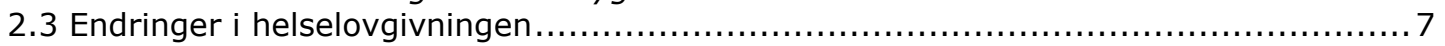

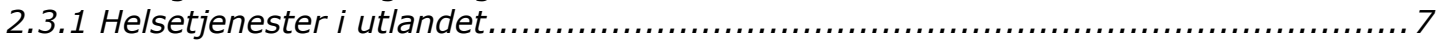

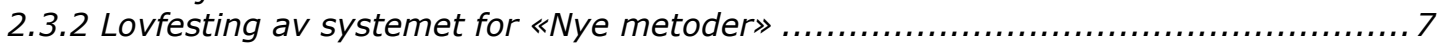

2.3.3 Dagaktivitet til hjemmeboende personer med demens.....................................

2.3.4 Egenandelstakene til helsehjelp sammenslâtt - frikortordningen........................8

2.3.5 Fosterreduksjon skal behandles etter abortlovens regler..............................8

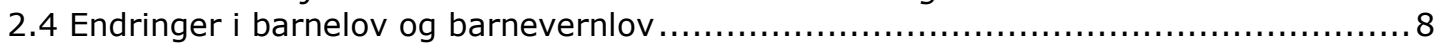

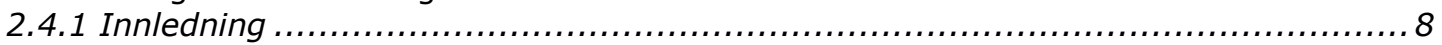




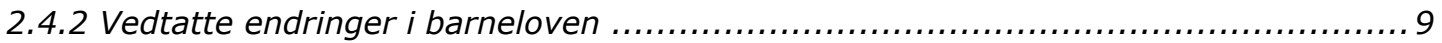

2.4.3 NOU 2020: 14 Ny barnelov ........................................................... 9

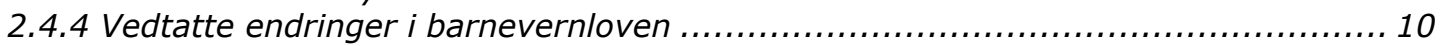

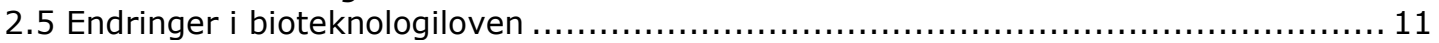

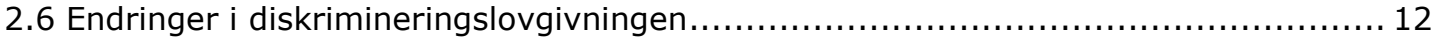

3. Statsbudsjettet 2021 og regjeringssammensetningen ............. 13

4. Pensjonsnivået og eldres $\emptyset$ konomi ................................. 14

4.1 Innledning 14

4.2 Regulering av grunnbeløpet og folketrygdens minsteytelser i $2020 \ldots \ldots \ldots \ldots \ldots \ldots \ldots \ldots$

4.3 Stortinget avviste bedret pensjon for offentlig ansatte som arbeider etter 67 år ..... 15

5. $\varnothing$ konomisk sosialhjelp ........................................ 16

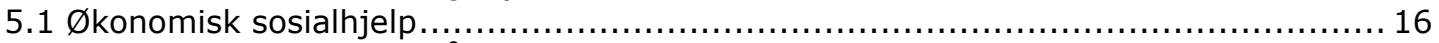

5.2 Plikt for kommunene til å stille krav om aktivitet og norskopplæring .................. 16

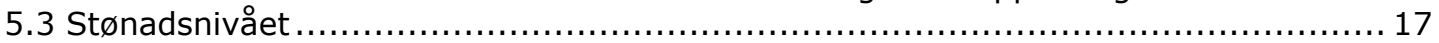

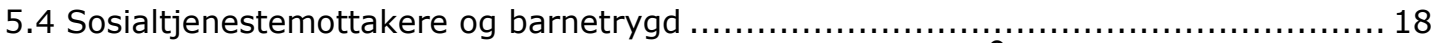

6. Stønadsvinnerne ved budsjettforlik de siste år.................... 19

6.1 Innledning 19

6.2 Minsteytelse og foreldrepenger ved fødsel, og om studentforeldre .................... 19

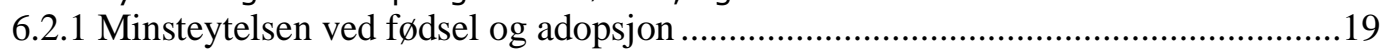

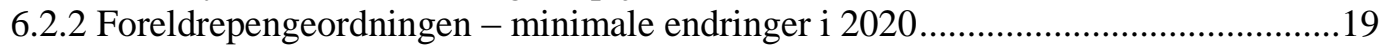

6.2.3 Noe mer om studenter med barn .................................................................20

6.3 Barnetrygden ble økt fra 2019 og øker på nytt for småbarn i 2021 ................... 21

6.4 Andre stønader forbundet med svangerskap, fødsel og adopsjon; minstebidrag ...... 22

6.5 Barnehagelov, barnehagepolitikk og SFO - regelendringer, foreldrebetaling og gratis

kjernetid 23

6.5.1 Viktige endringer i barnehageloven ....................................................23

6.5.2 Foreldrebetaling i barnehager mv. ............................................................23

6.5.3 Tak på SFO-betaling ................................................................................23

6.5.4 Utvidelse av ordningen med fritidskort til dekning av barns utgifter til

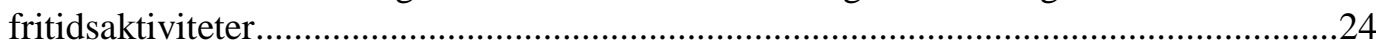

7. Begrenset $\varnothing$ kning i flere familieytelser .........................24

7.1 Innledning 24

7.2 Uendrede satser for grunnstønad, hjelpestønad, økte satser for utgifter til barnetilsyn i 202124

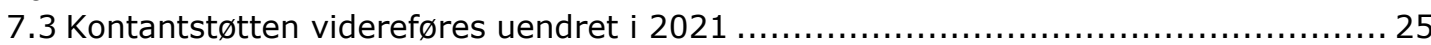

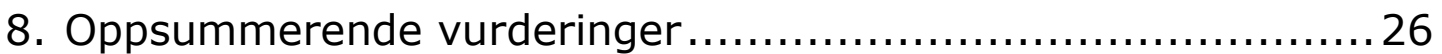

\section{Innledning}

Vanligvis har denne artikkelen startet med en generell $\varnothing$ konomisk oversikt og prognoser for kommende år, antall arbeidsledige mv. ${ }^{1}$

Koronapandemien har satt en stopper for denne type «spådommer» fra min side for 2021.

Samtidig har året 2020, etter at Norge stengte ned 12. mars (første smittebølge) og igjen på senhøsten (for å stoppe andre smittebølge), vært preget av mye ad hoc-lovgivning og tallrike forskriftsendringer for å følge opp ulike krisepakker og andre krisetiltak. Det handler om endringer i permitteringsreglene, dagpengesystemet mv. for å sikre midlertidige og mer permanente arbeidsledige noe bedre økonomi enn de vanlige reglene ville åpnet for, samt for å yte kompensasjonsordninger for foretak med stort omsetningsfall, kompensasjon for merutgifter og mindreinntekter til kommuner etc. for å minimere negative virkninger på norsk økonomi på lang sikt.

\footnotetext{
${ }^{1}$ Jeg takker seniorforsker Astri Syse og advokat Heidi Wyller for verdifulle tilbakemeldinger på et utkast til denne artikkelen.
} 
I begynnelsen av desember 2020 var nær 110000 personer registrert som helt ledige hos NAV. Dette utgjør 3,8 prosent av arbeidsstyrken. Bruttoledigheten, som er summen av antallet helt ledige og arbeidssøkere på tiltak, var på 123600 personer, eller 4,4 prosent av arbeidsstyrken.

I tillegg er 71500 personer registrert som delvis arbeidsledige. Totalt er dermed 195000 personer registrert som arbeidssøkere hos NAV, noe som utgjør 6,9 prosent av arbeidsstyrken.

SSB (Statistisk sentralbyrå) mener at dersom stordelen av befolkingen blir vaksinert i løpet av 2021, kan den totale arbeidsledigheten i 2022 falle ytterligere mot et normalnivå på 4 prosent.

Av de helt ledige er 30400 permitterte, og det samme gjelder for 31500 av de delvis ledige. Til sammen er 2,2 prosent av arbeidsstyrken permittert. Oslo er fylket med størst andel permitterte, med 3,7 prosent av arbeidsstyrken.

Ut fra Arbeidskraftsundersøkelsen (AKU) var arbeidsledigheten 5,2 prosent målt som gjennomsnitt fra august til oktober 2020. Det er de næringene som har vært direkte berørt av smitteverntiltakene, som i størst grad har opplevd nedgang i sysselsettingen. Dette gjelder for eksempel overnatting og servering samt kultur, underholdning og annen tjenesteyting. Selv om ledigheten trolig ikke reduseres mye de neste månedene, forventes det at situasjonen $\mathrm{i}$ arbeidsmarkedet bedres når den økonomiske aktiviteten tar seg opp utover i 2021. Ifølge SSBs beregninger vil arbeidsledigheten målt ved Arbeidskraftsunders $\varnothing$ kelsen bli 4,8 prosent i 2020, for deretter å falle gradvis til rundt 4 prosent i 2022 og 2023. Til sammenlikning har arbeidsledigheten vært 3,7 prosent i gjennomsnitt så langt på 2000-tallet.

Statsbudsjettet for 2022 er på over 1500 mrd. kroner. Det ble plusset på vel 18 mrd. kroner på utgiftssiden gjennom budsjettforhandlingene mellom regjeringen og FrP. Av disse ble ca. 4 mrd. inndekket gjennom å beskjære enkelte utgiftsposter, mens størstedelen (vel 14,5 mrd.) ble hentet fra oljefondet.

\section{Lovendringer i kraft fra 2020 og 2021}

\subsection{Innledning}

2020 ble et rekordår antall lovendringer og forskrifter. Mange av lovendringene og forskriftsendringene hadde med koronapandemien å gjøre. Bare covid-19-forskriften er blitt endret mer enn 60 ganger, avhengig av hvilke smittevernregler som skal gjelde.

Det ble i 2020 gitt til sammen 161 lover eller endringslover, 50 lover mer enn i foregående år. Langt de fleste vedtas og sanksjoneres i vårsesjonen som normalt er tiden for lovbehandlinger med begrenset budsjettbetydning. Høstsesjonen er kort, men ble i 2020 også preget av hektisk lovgivningsaktivitet. Ganske mange av lovforslagene er begrunnet i koronapandemien, og har en begrenset virkningstid. Inge Lorange Backer fastslår: «År om annet treffer Stortinget nå noe over 100 lovvedtak - fra omkring 80 til over $140 .{ }^{2}$ Årets antall overgår til og med etterkrigstidens behov for «oppgjøret» med krigstidens lovgivning. I 1946 ble det sanksjonert 159 lover, og i 1947 ble det sanksjonert 151 lover. $^{3}$

Denne artikkelen omhandler stort sett lovendringer i kraft i 2020 og for året 2021, og ikke tilbakeskuende om de rettslige debattene som har vært om smittevernloven og lovligheten av

\footnotetext{
${ }^{2}$ Inge Lorange Backer: Lov og lovgivning, Universitetsforlaget 2013, s. 18.

${ }^{3}$ Inge Lorange Backer: Loven - hvordan blir den til?, Universitetsforlaget 2013, s. 14.
} 
enkelte inngripende smitteverntiltak. Heller ikke vil jeg presentere de mange midlertidige lov- og forskriftsendringer som vil opphøre ved årsskiftet, eller når smittesituasjonen endrer seg, for eksempel ved en full vaksinering av befolkningen. Smittevernlovgivningen ligger også noe på siden av de rettsområdene FAB skal dekke.

Den nye arveloven trådte i kraft 1. januar 2021, og den er behørig presentert gjennom flere artikler i foregående årganger. ${ }^{4}$ Den behandles således ikke her. Viktige endringer i barnehageloven er behandlet sammen med $\emptyset$ vrige barnehagetiltak, se punkt 6.5

Ved årsskiftet 2020/2021 lå det 25 lovforslag på Stortingets bord og ventet på behandling. Seks av disse ble fremmet i statsråd så seint som 18. desember 2020. De færreste har imidlertid relevans for saksfeltene til FAB.

\subsection{Endringer i trygde- og pensjonsordninger}

\subsubsection{Trygdeskandalen og oppfølging av denne}

I løpet av høsten 2018 ble det klart at norske myndigheter siden (minst) 2012 - både i forvaltningen (NAV/Trygderetten) og på lovgiversiden (Arbeids- og sosialdepartementet) hadde forstått og praktisert vilkårene i den norske folketrygdloven i strid med EUs trygdeforordning som Norge er bundet av. Spesielt gjaldt dette eksport av sykdomsbaserte trygdeytelser som sykepenger og arbeidsavklaringspenger.

Feiltolkningen fikk store konsekvenser. I årene 2014-2019 antas 78 mennesker å være uriktig dømt for trygdesvindel på grunn av feil rettsanvendelse, en rekke personer ble idømt fengselsstraffer, enda flere fikk uriktige krav om tilbakebetaling, og en rekke stønadsberettigede fikk et feilaktig avslag på krav om ytelser pga. utenlandsopphold.

Flere granskinger ble iverksatt, den mest omfattende ble utført av et regjeringsoppnevnt utvalg, ledet av professor Finn Arnesen. Utvalget la i august 2020 fram NOU 2020: 9 Blindsonen. Gransking av feilpraktiseringen av folketrygdlovens oppholdskrav ved reiser $i$ EØS-området.

Ikke alle rettslige spørsmål er endelig avklart. Blant annet ba Høyesterett 30. juni 2020 om en rådgivende uttalelse fra EFTA-domstolen i en sak om arbeidsavklaringspenger og opphold i EU/EØS-området i forbindelse med gjenopptagelse av en konkret straffesak. EFTAdomstolen skal forelegges rettstilstanden både før og etter 1. juni 2012. En rådgivende uttalelse fra EFTA-domstolen og avklarende avgjørelse fra Høyesterett forventes tidligst å foreligge før sommeren 2021.

Et sentralt læringspunkt etter skandalen er at kompetansen om EØS-retten systematisk må styrkes $i$ alle ledd innenfor forvaltningen og domstolene, herunder i lovutredninger og dokumenter til Stortinget. Det er også tydelig at kommunikasjonen internt i NAV og mellom NAV, departementet, trygderetten og påtalemyndigheten må bli bedre.

\subsection{2 Økte krav til bosted og opphold i Norge}

Etter skandalen omkring NAVs håndtering av EØS-rettslig trygdelovgivning, se punkt 2.2.1, framsto det som påfallende at stortingsflertallet vedtok regjeringens forslag om et krav til

\footnotetext{
${ }^{4}$ Thomas Eeg: «Proposisjon om ny lov om arv og dødsboskifte», $F A B$ nr. 4 for 2018, s. 313-327; John Asland: «Digitale testamenter - muligheter, men viktige motforestillinger», FAB nr. 4 for 2019, s. 283-287; Per R

Fosmark: «Bokmelding Hambro: Arveloven. Arvereglene. Lovkommentar», FAB nr. 3-4 for 2020, s. 334-340.

${ }^{5}$ For oppdatering av status for trygdeskandalen kan man følge denne bloggen: https://www.jus.uio.no/om/aktuelt/retten-i-trygdeskandalen/
} 
bosted og opphold i Norge for rett til ektefelle- og barnetillegg. Forslaget ble vedtatt nær sagt uten at EØS-spørsmål ble vurdert i lovframlegget, se Prop. 129 L (2018-2019). ${ }^{6}$

Opposisjonen ønsket lovforslaget tilbakesendt regjeringen, og at det først ble fremmet ny sak etter at «årsakene til rettsskandalen med feil fortolkning av EØS-retten er avdekket og løsninger for å gjøre regelverket mer tilgjengelig er vurdert». Lovvedtaket fulgte like fullt regjeringens forslag, se Innst. 53 L (2019-2020).

For rett til barne- og ektefelletillegg (forsørgingstillegg) ved søknad om alderspensjon og uføretrygd stilles det fra 1. juli 2020 krav om bosetting og opphold i Norge for henholdsvis barn og ektefelle.

Endringene trådte i kraft fra 1. juli 2020, jf. Prop. 10 (2019-2020), Prop. 1 S (2019-2020). Endringene gis kun virkning for krav som settes fram etter ikrafttredelse.

\subsubsection{Nye regler for etterlatteytelser til ektefeller, tidligere familiepleiere og barn}

Ved endringslov 18. desember $2020 \mathrm{nr} .139$ ble det vedtatt helt nye regler for etterlatteytelser, og da basert på utredningen i Prop. 13 L (2020-2021) Endringer i folketrygdloven (nye etterlatteytelser). Kort sagt legges det til grunn at folketrygden i hovedsak skal gi individuelle rettigheter, enten basert på opptjening eller på botid. Dette med at etterlatte ektefeller skal kunne få overført deler av avdødes opptjente rettigheter etter folketrygdloven (ftrl.) ved dødsfall, er under avvikling.

Det tidligere ftrl. kap. 16 om ytelser til tidligere familiepleiere er vedtatt opphevd. Et nytt kapittel 17 vil omfatte både stønader til gjenlevende ektefelle og tidligere familiepleier.

Barnepensjoner som er regulert i ftrl. kap. 18, er på den andre siden vedtatt ved at grunnytelsen settes til 50 prosent (opp fra 40 prosent) av grunnbeløpet (G) for barn som har mistet én forelder, og til 120 prosent av grunnbeløpet for barn med søsken som har mistet begge foreldrene (tidligere utmålt som etterlattepensjon). For barn som har mistet begge foreldrene og som ikke har søsken som samtidig har rett til ytelse, foreslås det en forhøyet sats på 2,25 G, tilsvarende forslaget til sats i den standardiserte ytelsen til voksne etterlatte.

Departementet har i begrunnelsen for å forlate dagens system med avtrappende satser ved flere søsken lagt vekt på at det ikke er sterke holdepunkter for å anta at en husholdning med flere barn gir stordriftsfordeler. Standardiserte satser for ytelser til etterlatte ektefeller og barn vil samtidig forenkle regelverket betydelig.

Disse forslagene innebærer vidtgående endringer i dagens regelverk. For å sikre en betryggende saksbehandling foreslår departementet at NAV gis tilstrekkelig tid til å forberede innføringen av de nye reglene. Reformen kan derfor tidligst iverksettes fra 2023.

\subsubsection{Store endringer for personer med flyktningstatus - supplerende stønad}

Folketrygdlovens særskilte bestemmelser for flyktninger ga tidligere unntak fra krav til forutgående opptjening for en rekke ytelser, samt unntak fra reduksjon pga. manglende trygdetid for rett til fulle ytelser. Bortfallet av disse særordningene har ført til endringer i ftrl. $\S \S 1-7,3-2,3-3,3-9,11-2,12-2,12-3,12-13,12-15,15-2,17-3,17-4,17-7,18-2,18-3,18-5$, $19-2,19-3,19-8,20-10$ og 22-8. Hele definisjonsbestemmelsen om hvem som skal anses som «flyktning», i tidligere ftrl. § 1-7 er opphevd.

\footnotetext{
${ }^{6}$ Se endringslov 13. desember 2019 nr. 78 og relevante bestemmelser i ftrl. kap. 3 og kap. 12.
} 
Endringene trådte i kraft fra 1. januar 2021, jf. Prop. 10 (2019-2020), Prop. 1 S (2019-2020). Se også Prop. 85 L (2016-2017).

Endringene gis kun virkning for krav som settes fram etter ikrafttredelsesdato.

For alderspensjon skjermes personer født før 1960 og som har vært medlem minst 20 år per 1. januar 2021.

Dette medførte parallelt endringer i lov 29. april $2005 \mathrm{nr}$. 21 om supplerende stønad til personer med kort botid i Norge, som vil bli den aktuelle stønadsformen når særreglene for flyktninger bortfaller. Loven gjelder i dag for personer som har fylt 67 år og bor i Norge, og som da vil måtte benyttes i større grad enn tidligere av overføringsflyktninger, også ofte omtalt som «kvoteflyktninger». Supplerende stønad er behovsprøvd (inntektsprøvd).

Nivået på uavkortet, supplerende stønad (kalt «garantipensjonsnivå») er lovfastsatt til satsene som bestemmes i henhold ftrl. § 20-9 (ny alderspensjon), se $\S 2$ tredje ledd. Satsene som gjelder fra og med 1. mai 2020, er $192125 \mathrm{kr}$ (høy sats) og $177724 \mathrm{kr}$ (ordinær sats), sml. satsene i «gammel» alderspensjon i punkt 4.2. Denne endringen betyr en reell nedgang $\mathrm{i}$ stønadsnivået som tidligere var knyttet til pensjonsnivået i ftrl. kap. 19. For enslige er nedgangen på ca. 10000 kroner, mens for gifte/samboende blir reduksjonen i stønadsnivået på ca. 5500 kroner.

Alle over 67 år som mottar stønad, blir berørt av disse endringene som trådte i kraft fra 1. januar 2021.

I tillegg trådte flere av bestemmelsene i endringslov 20. desember 2019 nr. 84 i kraft fra 1. januar 2021. Dette gjelder endringene som hevet kravet til tidligere trygdetid/botid fra tre til fem år for rett til uføretrygd, alderpensjon, arbeidsavklaringspenger, stønad til mor/far med aleneomsorg for barn og barnepensjon. Disse lovendringene vil igjen ha stor betydning for personer som kommer til Norge som flyktninger.

\subsubsection{Flere mindre endringer i folketrygdloven}

Regjeringen framla parallelt med statsbudsjettet en samleproposisjon med enkelte innstramninger på folketrygdens område, se Prop. 27 L (2020-2021).

Proposisjonens punkt 2, 3 og 4 gjelder lovendringer som er nødvendige for å følge opp forslag som ble fremmet i statsbudsjettet.

Særlig i dagpengereglene (punkt 2 og 3) gjøres det like fullt unntak pga. koronasituasjonen med høyere satser. Viktig er midlertidige endringer i ftrl. § 4-6 (dagpenger under utdanning, opplæring, etablering av egen virksomhet mv.) som åpner for at dagpenger under arbeidsløshet uten hinder av ftrl. § 4-6 første ledd kan kombineres med utdanning eller opplæring. Dette er en positiv utvidelse som muliggjør kvalifisering under arbeidsledighet uten tap av dagpenger.

Regjeringen foreslår endringer i ftrl. §§ 4-25 og 4-25 slik at dagpengene også skal samordnes mot reduserte pleiepenger, omsorgspenger og opplæringspenger etter ftrl. kap. 9.

På den andre siden forlenges ventetiden før arbeidsledige får rett til dagpenger dersom vedkommende anses å være arbeidsledig «uten rimelig grunn». Det kan for eksempel skje ved at vedkommende frivillig har valgt å si opp arbeidsforholdet eller ved å bli avskjediget. Denne ventetiden $\varnothing$ kes fra 12 til 18 uker fra 1. januar 2021. Mottakere av dagpenger som «uten rimelig grunn» takker nei til tilbud om jobb/ eller lar være å søke egnet arbeid, kan miste dagpenger i 18 uker. Disse regelendringene ble foretatt i henholdsvis ftrl. § 4-10 og § 420. 
Permitteringsreglene har vært under stadig endringer. I januar 2021 vedtok stortingsflertallet, dvs. «firerbanden» av Ap, FrP, Sp og SV, at permitterte arbeidstakere skal kunne gå permittert fram til 1. oktober 2021, og der utgiftene til dagpenger under permitteringstiden skal dekkes av statlige midler.

Dessuten fortsetter opphevingen av særreglene som tidligere gjaldt for flyktninger. Nå er det etterlatteytelsene som skal «normaliseres»; forslaget om dette kan ses i sammenheng med Prop. 13 L (2020-2021), se punkt 2.2.3.

\subsection{Endringer i helselovgivningen}

\subsubsection{Helsetjenester i utlandet}

Ved endringslov 20. desember 2019 nr. 104 ble det vedtatt viktige endringer i pasient- og brukerrettighetsloven (pbrl.), se Prop. 80 L (2018-2019). Dette gjelder muligheten for å kunne motta helsetjenester i utlandet, og er samtidig en tydeliggjøring av rettigheter norske pasienter har etter EUs pasientrettighetsdirektiv.

Ny pbrl. § 2-4a begynner slik: «Pasient har rett til å få utgifter til helsehjelp som mottas i et annet EØS-land, helt eller delvis dekket etter ftrl. § 5-24 a med forskrifter som gjennomfører pasientrettighetsdirektivet i norsk rett» (bokstav a).

Bestemmelse i pbrl. § 2-4a gir videre en oversikt over de ulike ordningene som kan gi grunnlag for utgiftsdekning av helsehjelp $\mathrm{i}$ andre EØS-land og i utlandet ellers.

Retten til å motta nødvendig helsehjelp i utlandet fordi det ikke finnes et tilbud i Norge, som tidligere var regulert i pbrl. § 2-1b femte ledd, flyttes til ny pbrl. § 2-4a andre ledd bokstav a, hvor det presiseres at rettigheten også omfatter helsehjelp i utlandet som er «dokumentert mer virkningsfull».

Reglene trådte i kraft 1. mars 2020.

\subsubsection{Lovfesting av systemet for «Nye metoder»}

Ved endringslov 20. desember 2019 nr. 103 ble det gitt regler i spesialisthelsetjenesteloven (shl.) som avgrenser hvilke plikter det offentlige har til å godkjenne nye metoder og legemidler, og hvordan slik godkjenning skal skje. Systemet pålegger de regionale helseforetakene (RHF) å etablere et felles system for dette, under RHF-enes «sørge-foransvar», se shl. § 4-4 første ledd.

Samtidig ble det presisert i pbrl. § 2-1b om nфdvendige spesialisthelsetjenester at rettigheten «gjelder de tjenestene som spesialisthelsetjenesten har ansvaret for å yte og finansiere», med henvisning til shl. §§ 2-1a og 4-4, se Prop. 55 L (2018-2019) Endringer $i$ spesialisthelsetjenesteloven og pasient- og brukerrettighetsloven (lovfesting av systemet for nye metoder m.m.).

Det presiseres i loven at pasienter heller ikke kan betale for å motta en høyere standard på helsehjelpen enn det som tilbys etter shl. § 2-1a, se pbrl. § 2-1b andre ledd siste punktum.

Reglene trådte i kraft 1. januar 2020.

\subsubsection{Dagaktivitet til hjemmeboende personer med demens}

Ved endringslov 21. juni 2019 nr. 45 ble det lovfestet en kommunal plikt til å ha dagaktivitetstilbud til hjemmeboende personer med demens. Men dette ble ikke gitt som en (ny) rettighet i pasient- og brukerrettighetsloven, men pålagt kommunen som en pliktig ytelse 
etter helse- og omsorgstjenesteloven $\S 3-2$ første ledd (nytt) nr. 7. Regelfestingen innebærer derfor kun en plikt for kommunen til å opprette og ha en slik tjeneste, se Prop. 66 L (20182019) Endringar i helse- og omsorgstenestelova (dagaktivitetstilbod til heimebuande personar med demens).

\subsubsection{Egenandelstakene til helsehjelp sammenslått - frikortordningen}

For personer med store utgifter til dekning av helsehjelp, medikamenter mv. var det inntil 2020 to egenandelstak, kalt henholdsvis egenandel I (legehjelp, medisiner mv.) og egenandel II (fysioterapi mv.). Disse to egenandelstakene er nå slått sammen og gjelder a) legehjelp, b) psykologhjelp, c) viktige legemidler og spesielt medisinsk utstyr, d) reiseutgifter, jf. spesialisthelsetjenesteloven $\S 5-5 \mathrm{nr}$. 4, e) radiologisk undersøkelse og behandling, f) laboratorieprøver, g) helsehjelp som utføres poliklinisk, h) tannlege- og tannpleierhjelp, i) fysioterapi, j) opphold ved opptreningsinstitusjoner og andre private rehabiliteringsinstitusjoner som har driftsavtale med regionalt helseforetak, k) behandlingsreiser til utlandet (klimareiser), se Prop. 16 L (2020-2021) og Innst. 129 L (2020-2021).

I statsbudsjettet var dette samlede egenandelstaket foreslått til over 3000 kroner, men gjennom budsjettforliket mellom regjeringspartiene og FrP ble det nye felles taket for rett til frikort med utvidet dekningsordning stående uendret på 2460 kroner slik beløpet var for rett til frikort for legetjenester og medikamenter.

Både denne endringen og endringen i pensjonene medførte utgifter på over én milliard for 2021.

\subsubsection{Fosterreduksjon skal behandles etter abortlovens regler}

Som konsekvens av at regjeringen ble utvidet med medlemmer fra Kristelig Folkeparti $(\mathrm{KrF})$, la regjeringen fram forslag om at søknad om fosterreduksjon, der kvinnen bærer på et flerlingesvangerskap og ønsker en reduksjon av antallet fostre, skal behandles etter abortlovens regler. Dette innebærer samtidig at søknaden skal avgjøres av en abortnemnd, uavhengig av svangerskapets lengde, se ny abortlov $\S 2 \mathrm{a}$.

Endringslov 21. juni 2019 nr. 44 til abortloven trådte i kraft 1. september 2019.

Selv om endringene i praksis vil bety lite, er dette første innstramning i kvinners rett til å bestemme i abortvalgsituasjonen siden 1977.

\subsection{Endringer i barnelov og barnevernlov}

\subsubsection{Innledning}

I 2020 ble det, i motsetning til tidligere år, vedtatt få endringer i barneloven og barnevernloven.

Ellers framla Frantzen-utvalget NOU 2020: 14 Ny barnelov - Til barnets beste i desember 2020. Den gis en kort omtale i punkt 2.4.3. En bredere omtale vil komme i et senere nummer.

Det er vedtatt enkelte lovendringer i barnevernloven i løpet av 2020; disse er omtalt i punkt 2.4.4.

Forslag til ny barnevernslov er ventet framlagt våren 2021, og kanskje tidsnok til å kunne bli vedtatt i løpet av vårsesjonen. 


\subsubsection{Vedtatte endringer i barneloven}

Bare i begrenset utstrekning ble det gitt nye regler i barneloven (bl.) i 2020. Dette har sikkert sammenheng med at hele loven er under revidering.

En ny bestemmelse i bl. $\S 4$ andre ledd åpner for digital erklæring av farskap til NAV. En forutsetning for at farskap skal kunne erklæres digitalt, er at barnet fødes i Norge.

I tilfeller hvor farskap er erklært digitalt før fødselen, og barnet likevel blir født i utlandet, vil farskapet måtte fastsettes ved farskapserklæring på papir, etter fødselen. Den digitale erklæringen som tidligere er avgitt, kan da ikke legges til grunn, se Prop. 97 L (2019-2020).

Moren må enten oppgi hvem som er faren til barnet, eller godta hans erklæring i ettertid. Godkjenningen må gjøres på en måte som er etterprøvbar, enten at den nedtegnes på papir eller gjøres digitalt. Ved tvillingsvangerskap signerer faren én erklæring dersom dette gjøres før fødselen, eller én erklæring for hvert barn, om dette skjer etter fødsel.

Bestemmelsen trådte i kraft 1. januar 2021.

\subsubsection{NOU 2020: 14 Ny barnelov}

Et lovutvalg ble oppnevnt 7. desember 2018 ledet av lagdommer Torstein Frantzen for å utarbeide utkast til ny barnelov. Utvalget skulle gjennomgå barneloven og barns rettigheter blant annet i lys av menneskerettighetene. Ifølge oppdraget skal foreldrene i den nye loven være likestilte som foreldre, omsorgspersoner og forsørgere. Hensynet til barnets beste skal være avgjørende. NOU 2020: 14 Ny barnelov - Til barnets beste ble overlevert 4. desember 2020 etter knappe to års utvalgsarbeid.

Diskusjonen etter avleveringen av lovutkastet har dreid seg mest om et krav til samtykke fra den andre forelderen når den ene forelderen ønsker å flytte innenlands med barnet.

I lovutkastet kap. 1 fastslås fire prinsipper om barns rettsstilling. Disse er: i) Det beste for barnet ( $(1-1)$; ii) Barnet sin rett til medverknad ( $\$ 1-2)$; iii) Barnet sin rett til omsorg, utvikling og vern mot vald (§ 1-3); og iv) Barnet sin rett til familieliv (§ 1-1). Det er både skrevet et eget forord til barn og et eget sammendrag for barn.

En rask gjennomlesing av lovutkastet antyder at det foreslås få større endringer i relasjon til dagens lov, men barnets selvstendige rettigheter er betraktelig styrket i forhold til dagens lov ut fra de forannevnte prinsipper som er lagt til grunn for lovutkastet.

Utvalget foreslår status quo hva gjelder fastsetting av morskap og farskap. Som leder av farskapsutvalget ${ }^{7}$ sjekket jeg om utvalget foreslår endringer i fastsetting av juridisk morskap og farskap i og med at eggdonasjon nå er blitt tillatt, se punkt 2.5.

Utvalget holder fast på «mater est»-regelen i lovutkastet kap. 2. I § 2-1 fastslås at foreldreskap til et barn skal fastsettes etter barneloven eller adopsjonsloven. Videre heter det: «Eit barn kan ikkje ha fleire enn to foreldre.» I § 2-2 fastslås at «den som har født barnet, er mor til barnet» (gjelder også eventuelt en juridisk mann). Heller ikke kan morskap «overførast gjennom avtale om å føde eit barn for ein annan person».

I $~ 2-3$ reguleres foreldreskap etter assistert befruktning.

I § 2-4 videreføres «pater est»-regelen: «Dersom mora var gift med ein mann då barnet vart født, er mannen far til barnet.» Bestemmelsen gjelder ikke - slik tilfellet også er i dag dersom ektefellene var separert da barnet ble født.

\footnotetext{
${ }^{7}$ NOU 2009: 5 Farskap og annen morskap.
} 
Videre kan farskap - som i dag - fastsettes etter erklæring ( $\$ 2-5)$, og videre i kapitlet reguleres blant annet situasjonen når en annen person erklærer farskap.

Utgangspunktet for foreldreansvaret er som nå at dette skal være felles for samboere og personer som er gift, se NOU kapittel 10. Men det er ulike flertall/mindretall vedrørende reglene om fastsetting og endring av foreldreskap, og ved foreldreskap der én forelder alene har omsorgen for barnet mv.

Også der barnevernet er involvert i foreldretvistsaker, deler utvalget seg i flere fraksjoner, se NOU kapittel 14.

Selve lovutkastet er på 15 kapitler. Som nevnt vil NOU 2020: 14 bli mer utdypende presentert $i$ et senere nummer.

\subsubsection{Vedtatte endringer i barnevernloven}

Ved endringslov 19. juni 2020 nr. 74 ble det foretatt endringer med sikte på å styrke rettssikkerheten til barn og foreldre gjennom riktigere hjelp og bedre beskyttelse, se Prop. 84 L (2019-2020) Endringer i barnevernloven (samtaleprosess, årlig tilstandsrapportering $m v$.).

Det ble vedtatt blant annet å utvide aldersgrensen for rett til ettervern til 25 år og å innføre samtaleprosess som en alternativ prosessform i fylkesnemndene, se endringene i bvl. kap. 7. Dessuten er det innført krav om årlig rapportering til kommunestyret om tilstanden i barnevernstjenesten.

Det ble også gitt bestemmelser knyttet til meldinger til barnevernet, og tilbakemelding om det er åpnet undersøkelsessak, samt plikt til å gi informasjon til politiet om vedtak om skjult adresse.

Den redigerte bestemmelsen om samtaleprosess i bvl. § 7-25 er gitt følgende ordlyd:
«Nemndlederen kan tilby partene å delta i en samtaleprosess som alternativ til ordinær behandling, dersom saken er egnet for det. Formålet med samtaleprosessen er å bedre partenes kommunikasjon og gi dem mulighet til å bli enige om løsninger til barnets beste som hel eller delvis løsning på saken.
Partene må samtykke til å delta i samtaleprosessen. Private parter skal representeres av advokat. Nemndlederen kan oppnevne en sakkyndig for å bistå i samtaleprosessen.
Nemndlederen skal påse at hensynet til barnets beste og de private partenes rettssikkerhet blir ivaretatt Nemndleder kan gi partene anledning til å prøve ut en midlertidig ordning for en nærmere fastsatt tid. Nemndlederen kan når som helst avbryte samtaleprosessen og henvise saken til ordinær behandling.
Departementet kan gi forskrift om gjennomføring av samtaleprosesser, herunder om unntak fra fristkravene i kapittel 4 og 7.»

Enkelte endringsbestemmelser trådte i kraft i 2020; de øvrige trådte i kraft 1. januar 2021.

Videre ble det gjennom eget lovvedtak foretatt endringer i internkontrollreglene $\mathrm{i}$ sektorlovgivningen, herunder barnevernloven, for å tilpasse bestemmelsene til ny kommunelov, se Prop. 81 L (2019-2020).

Etter bvl. § 2-1 andre ledd skal kommunen ha internkontroll etter reglene i kommuneloven $\S$ 25-1. Videre skal Fylkesmannen etter bvl. $\S 2-3$ b andre ledd føre tilsyn med lovligheten av kommunens oppfyllelse av plikter etter bvl. kap. 1 til 9 og kommuneloven (koml.) § 25-1. Reglene i koml. kap. 30 gjelder for denne tilsynsvirksomheten.

Disse reglene trådte i kraft 1. januar 2021. 
Ellers vises til grundige artikler om Høyesteretts praksis og praksis fra EMD på barnevernrettens område, særlig hva gjelder inngripende tiltak mot foreldrenes $\emptyset$ nsker, med hjemmel i bvl. kap. $4 .^{8}$

\subsection{Endringer i bioteknologiloven}

Stortinget vedtok 8. juni 2020 flere endringer i bioteknologiloven (lov 5. desember $2003 \mathrm{nr}$. 100 - biotl.). De fleste av endringene trådte i kraft fra 1. juli 2020. Endringene som åpner for eggdonasjon, skulle senest tre i kraft 1. januar 2021.

Blant endringene som trådte i kraft fra 1. juli 2020, er:

- Assistert befruktning til enslige er blitt tillatt (biotl. § 2-2).

- Aldersgrense for kvinne som mottar assistert befruktning, er satt til 46 år (ny biotl. § 2-3a).

- Femårsgrensen for lagring av befruktede egg oppheves. Virksomhetene plikter å oppbevare befruktede egg til kvinnen egget skal settes inn i, er fylt 46 år. Virksomheten kan fastsette en kortere lagringstid på bakgrunn av ressurs- og nyttehensyn, men ikke kortere enn fem år etter at egget ble befruktet.

- Behandlende lege skal få innsyn i relevant taushetsbelagt informasjon om søker av assistert befruktning. Det kreves samtykke fra den opplysningene gjelder. Den som søker om assistert befruktning, må framlegge barneomsorgsattest. Behandlende lege kan be om en vurdering fra en instans bestemt av departementet i særlige tilfeller der legen er i tvil om omsorgsevnen til kvinnen eller paret som søker assistert befruktning (biotl. § 2-6).

- Ved bruk av lagrede, befruktede egg sammen med ny partner skal samtykke innhentes fra kvinnen og hennes nåværende ektefelle eller samboer. Det forutsettes at egget er befruktet med donorsæd (biotl. $\S 2-5$ tredje ledd).

- Gjenlevende samboer/ektefelle kan benytte lagret sæd fra avdøde eller egg som er befruktet med avdødes sæd, til assistert befruktning. Det må være dokumentert at det er avdødes ønske (biotl. § 2-17).

Stortinget har åpnet for eggdonasjon i Norge, og disse spørsmålene er nå regulert i biotl. $\S \S$ 2-8 til 2-10. Etter $§ 2-8$ skal det opprettes et donorregister der eggdonorers og sæddonorers identitet framgår, slik at barnets rett etter $§ 2-7$ til å kjenne sitt biologiske opphav fra 18årsalder kan oppfylles.

Etter biotl. § 2-9 skal en sæddonor være over 18 år og ikke fratatt rettslig handleevne på det personlige området. En eggdonor skal være over 25 år, og ikke eldre enn 35 år, og ikke fratatt rettslig handleevne på det personlige området. Donoren må gi skriftlig samtykke til at sæden eller de ubefruktede eggene kan brukes til befruktning, og at hans eller hennes identitet registreres i donorregisteret. Samtykke kan tilbakekalles fram til befruktningen har funnet sted. En sæddonor eller eggdonor skal ikke gis opplysninger om kvinnens, parets eller barnets identitet.

Etter biotl. § 2-10 er det behandlende lege som skal velge egnet eggdonor eller sæddonor. Virksomheten som utfører den assisterte befruktningen, skal sørge for at nødvendige opplysninger om behandlingen registreres og meldes.

\footnotetext{
${ }^{8}$ Se Kirsten Sandberg: «Storkammeravgjørelsene om barnevern», $F A B$ nr. 2 for 2020, s. 148-159, og Karl Harald Søvig og Per Harald Vindenes: «Avgjørelser fra EMD i saker om vern av privat- og familieliv fra 2019$2020 », F A B$ nr. 3 og 4 for 2020 , s. $173-209$.
} 
Fertilitetsseksjonen ved St. Olavs hospital regner med å etablere et tilbud med eggdonasjon i løpet av 2021. Allerede nå etterspørres mulige eggdonorer på deres hjemmeside. Tre institusjoner har allerede meddelt sin interesse for oppstart.

- Vedrørende fosterdiagnostikk åpnet stortingsflertallet for å ta i bruk NIPT (Non-Invasive Prenatal Test) som er en relativt ny blodprøve som tas av mor og kan utføres fra 9. til 11. svangerskapsuke og kan gi informasjon om fosterets utvikling og helsetilstand. I budsjettforhandlingene mellom regjeringen og FrP i desember 2020 ble det flertall for følgende verbalforslag: «Stortinget ber regjeringen innen 1. april [2021] få på plass en godkjenningsordning for private aktører som vil tilby NIPT, i tråd med føringene fra Stortingets flertall i Innst. 296 L (2019-2020).»

- Store deler av biotl. kap. 6 om genetiske unders $\phi$ kelser er omskrevet. De tidligere detaljerte krav i loven om genetisk veiledning er fjernet og erstattet med en bestemmelse om at pasienten skal få tilpasset genetisk veiledning. Formålet med den genetiske undersøkelsen avgjør hvordan den skal reguleres (om den skal defineres som prediktiv eller diagnostisk). Forbudet mot bruk av prediktiv genetisk informasjon utenfor helsetjenesten (forsikringsselskaper, arbeidsgivere m.m.) gjelder også dersom en diagnostisk genetisk unders $\varnothing$ kelse gir genetiske opplysninger om risiko for framtidig sykdom.

Bioteknologiloven skal bare gjelde forskningsprosjekter der deltakere får helsehjelp, og prosjekter der deltakerne skal få individuell tilbakemelding om resultatet av prediktive genetiske undersøkelser.

- Hele biotl. kap. 7 om genterapi er omskrevet. Definisjon av genterapi i bioteknologiloven blir lik definisjonen i EUs regelverk (biotl. § 7-1). Genterapi skal kunne brukes ved behandling av alle typer sykdommer, ikke bare dem som karakteriseres som alvorlige (biotl. $\S 7-2$ ). Kravet om godkjenning av genterapi etter bioteknologiloven oppheves (biotl. § 7-3).

Det ble tydeliggjort under Stortingets behandling at dobbeltdonasjon (samtidig egg- og sæddonasjon) fortsatt ikke er tillatt. Surrogati er også fortsatt forbudt i Norge.

\subsection{Endringer i diskrimineringslovgivningen}

Ved endringslov 21. juni 2019 nr. 57 ble det vedtatt viktige endringer i både diskrimineringsombudsloven og likestillings- og diskrimineringsloven. Blant de viktigste forslagene i Prop. 63 L (2018-2019) var etablering av et lavterskeltilbud for håndheving av forbudet mot seksuell trakassering i likestillings- og diskrimineringsloven. Det har lenge vært etterspurt et slikt lavterskeltilbud og et styrket veilednings- og hjelpetilbud for personer som utsettes for seksuell trakassering.

Videre ble offentlige virksomheter og private virksomheter med over 50 ansatte pålagt en skjerpet aktivitets- og redegjørelsesplikt for arbeidet mot diskriminering.

Likestillings- og diskrimineringsombudet har ansvaret for veiledning og oppfølging av aktivitets- og redegjørelsesplikten, både for private og offentlige aktører. Eventuelle brudd på aktivitetspliktene sanksjoneres ikke, mens Diskrimineringsnemnda håndhever arbeidsgivers redegjørelsesplikt. Diskrimineringsnemnda kan pålegge virksomheter å rette opp manglende oppfyllelse av redegjørelsesplikten, og eventuelt ilegge tvangsmulkt for å sikre oppfyllelsen.

Lovendringene trådte i kraft 1. januar 2020.

Det ble ikke foretatt endringer i diskrimineringslovgivningen i løpet av 2020. 


\title{
3. Statsbudsjettet 2021 og regjeringssammensetningen
}

Statsbudsjettet for 2021 ble, i motsetning til det foregående statsbudsjettet for 2020, framlagt av en mindretallsregjering Solberg $(\mathrm{H}, \mathrm{V}, \mathrm{KrF})$. FrP forlot regjeringen 24. januar rett før pandemien rammet Norge med nær sagt full nedstenging 12. mars 2020.

I budsjettsammenheng førte dette til langdryge forhandlinger hvor utgangspunktet var et begrenset handlingsrom pga. økonomisk nedgang under pandemien. Ved å ta i bruk nye 14 mrd. fra oljefondet ble de tre regjeringspartiene og FrP enige i sluttfasen, noe som førte til diverse påplussinger på mange ulike områder. Bortfall av passasjeravgiften for flybruk koster over én milliard, og «grensehandelspakken» (nedsatte avgifter på snus, $\varnothing 1$ og vin og bortfall av sukkeravgift) kostet 3,4 mrd. De fleste andre påplussingene, blant annet på familie- og velferdsområdet - bortsett fra trygdeøkningen til minstepensjonistene og en bedret beregning av pensjoner (se punkt 4.2 og 4.3) og senkning av egenandelstaket for helsetjenester (se punkt 2.3.4) - gjaldt en hel rekke mindre beløp.

Budsjettforliket i 2019 mellom den daværende trepartiregjeringen og Kristelig Folkeparti $(\mathrm{KrF})$ førte til den første $\varnothing \mathrm{kningen} \mathrm{i} \mathrm{barnetrygdsatsene} \mathrm{på} \mathrm{flere} \mathrm{tiår,} \mathrm{noe} \mathrm{som} \mathrm{er} \mathrm{videreført} \mathrm{med}$ økninger for barn under seks år i 2020 og 2021 (punkt 6.3). Også engangsstønaden i foreldrepengeordningen fikk et vesentlig løft ved samme forhandlingsrunde i 2019. Disse påplussingene blir videreført og økt i 2021 (punkt 6.2.1), mens regelverket for foreldrepenger forble uendret. Her er det foreslått regelendringer som hindrer «fedrefellen» ved at fedre kan miste rett til foreldrepenger (inkludert fedrekvoten) om de ikke melder uttakstidspunktet til NAV. Høringsutkast er sendt (høringsfrist 22. desember) hvor hovedinnholdet er at uttak av foreldrepenger for framtiden kan utsettes og tas ut når det passer innenfor treårsfristen.

Det er mye snakk om Forskjells-Norge, og det er dokumentert at formuesforskjellene i Norge er $\varnothing$ kende om man sammenlikner de 10 prosent med størst formue med de 10 prosent som har minst. Denne ulikheten $\varnothing$ ker imidlertid ikke like raskt som i land vi ofte sammenlikner oss med.

Også inntektsforskjellene blant arbeidsfolk øker (SSB). I år 2000 tjente den lavest lønnede tiendedelen i industri, bygg og hotell mellom 58 prosent og 55 prosent av den tiendedelen som tjente mest. I 2016 var denne andelen redusert til mellom 51 prosent og 47 prosent.

Den største bekymringen for politikere - og oss andre - ligger i at det stadig er flere barn som vokser opp i familier med samlede inntekter under fattigdomsgrensen, se også punkt 8 . NAVs rapport «Fattigdom og levekår i Norge» dokumenterte $\emptyset$ kte forskjeller i Norge, særlig blant barnefamilier med innvandringsbakgrunn, ungdom og unge voksne. ${ }^{9}$

Den nylig framlagte NOU 2020: 16 Levekår i byer - Gode lokalsamfunn for alle dokumenterer på en illustrerende måte hvordan levekårene innad i byene også er knyttet til geografi, slik at barnefattigdom, skolefrafall, trangboddhet og avhengighet av overføringer henger nøye sammen. Utvalget skriver blant annet:

\begin{abstract}
«Den sosioøkonomiske segregeringen i Norge har økt noe de siste tiårene. En gjennomgang av den sosioøkonomiske sammensetningen av boområder i Norge i perioden 1992-2015 viser at områdene over tid er blitt mer ensartede innad, og at det er blitt vanligere å bo enten i et lavinntektsområde eller et høyinntektsområde (Markussen og Røed 2018). Det ser altså ut til å ha blitt mindre forskjeller internt i nabolagene, men større forskjeller fra område til område. Segregeringen ser først og fremst ut til å ha $\emptyset k t$ i Oslo og Oslo-regionen (Wessel 2016, Andersen og Ljunggren 2016, Hernæs mfl. 2020).»
\end{abstract}

Frafallet i videregående skole holder seg høyt, og stadig flere mangler kompetansen som etterspørres av arbeidsgivere. Flere ungdommer synes å få vanskeligheter i livet, som utløser

\footnotetext{
${ }^{9}$ «Fattigdom og levekår i Norge. Tilstand og utviklingstrekk - 2017», NAV-rapport nr. 4 for 2017.
} 
et behov for koordinerte tilbud fra barnevern og psykisk helsevern. Det er også personer med marginal tilknytning til arbeidslivet som er blitt hardest rammet under nedstengninger som følge av pandemien. Mange personer er derfor avhengige av en godt fungerende og samordnet offentlig velferdsforvaltning.

I budsjettforslaget for 2020 flyttet stortingsbehandlingen på 1,8 mrd. av samlede budsjetterte utgifter på 1425 mrd. Dette utgjorde skarve 0,12 prosent av budsjettets utgiftsside. For 2021 ble som nevnt budsjettets utgiftsside $\varnothing \mathrm{kt}$ med 14,6 mrd., av $1513 \mathrm{mrd}$., dvs. 0,96 prosent.

Ved reetablering av en trepartiregjering gjennom FrPs utmarsj i 2020 ble det foretatt flere endringer i regjeringssammensetningen på de feltene som tas opp i denne artikkelen. Barneog familieminister Kjell Ingolf Ropstad (KrF) har fortsatt ansvar for regjeringens politikk knyttet til barn og unges oppvekst- og levekår, familie og samliv, tro og livssyn og forbrukerpolitikk. Bent Høie (H) har som helse- og omsorgsminister ansvaret spesialisthelsetjenesten, rus og psykisk helsevern, skolehelsetjenesten, kommunale helse- og omsorgstjenester og folkehelsepolitikken. Kunnskaps- og integreringsminister Guri Melby (V) har fått ansvar for å gjennomføre regjeringens politikk for barnehager, grunnskole, videregående opplæring og integrering.

Arbeids- og sosialminister Torbjørn Røe Isaksen (H) har ansvar for politikken knyttet til arbeidsmarked, arbeidsmiljø, pensjoner og velferd. Han overtok i januar 2020 etter Anniken Hauglie $(\mathrm{H})$ som hadde vært minister siden 2015. Mest sannsynlig var avgangen knyttet til NAV-skandalen høsten 2019, men uten at dette er blitt uttalt offentlig.

Regjeringens plattform og handlingsprogram er nedfelt i Granavolden-erklæringen som ligger lett tilgjengelig på regjeringens nettsider. ${ }^{10}$

\section{Pensjonsnivået og eldres økonomi}

\subsection{Innledning}

I fjorårets artikkel var det et lengre avsnitt om pensjonistenes levekår, som viser at det gjennom de siste årene har vært en bedring i pensjonisters økonomi. Dette skyldes ikke primært $\varnothing \mathrm{kningene}$ i pensjonene, men endrede skatteregler, egne stortingsvedtak om $\varnothing \mathrm{kning}$ av minsteytelsene, og en særlig $\varnothing \mathrm{kning}$ av grunnpensjonen for gifte og samboende pensjonister. Framstillingen var basert på Meld. St. 4 (2019-2020) Regulering av pensjoner $i$ 2019 og pensjonisters inntektsforhold. ${ }^{11}$

I samband med statsbudsjettdrøftingene 2021 ble det på nytt vedtatt særlig økning av minstepensjonene. Først kom et oppsiktsvekkende, felles opptrinn på Stortinget med Siv Jensen fra FrP, Audun Lysbakken fra SV, og Jan Davidsen, leder av Norsk Pensjonistforbund, som hadde med en rekke ulike forslag om $\varnothing \mathrm{kning}$ av pensjoner og $\varnothing \mathrm{kt}$ innflytelse for Norsk Pensjonistforbund i drøftinger med myndighetene, se Dokument 8: $53 \mathrm{~S}$ (2020-2021). Etter hvert syntes flere partier å ville slutte seg til flere av forslagene.

Stortinget ble enige om - som en «julegave» til minstepensjonistene - at enslige minstepensjonister får en ekstrapott på 4000 kroner. Dette gjelder bare dem som var minstepensjonister i 2020, men pengene kommer til utbetaling i 2021.

Videre ble det vedtatt at pensjons $\varnothing$ kningene inngikk i budsjettforhandlingene mellom regjeringen og FrP.

\footnotetext{
${ }^{10} \mathrm{https}$ //www.regjeringen.no/no/dokumenter/politisk-plattform/id2626036/

${ }^{11}$ Se $F A B$ nr. 1 for 2020 , s. 22-26.
} 
De mer varige pensjonsendringene kan oppsummeres slik:

1. I samband ned trygdeoppgjøret for 2021 tas det utgangspunkt $\mathrm{i}$ at alderspensjonistene skal få en vekst tilsvarende gjennomsnittet av lønns- og prisvekst dersom lønnstakerne antas å få positiv realvekst, og ikke taper mer enn lønnstakerne dersom realveksten for lønnstakerne antas å bli negativ.

Forskjellen blir både en ulik utgangsberegning for reguleringen samt at fratrekket på 0,75 prosent ikke skal gjelde for 2021 ved trygdeoppgjøret.

2. I tillegg er det lagt inn en ytterligere $\varnothing \mathrm{kning}$ i pensjonen til enslige minstepensjonister på 5000 kroner per år fra 1. juli 2021. Dette vil koste 2 mrd. i 2021, og vil være vanskelig å begrense i etterfølgende trygdeoppgjør.

Ved utgangen av juni 2019 var det 947900 personer som mottok alderspensjon. Antallet alderspensjonister vil vokse også i årene framover. NAVs prognose er at antallet vil passere én million i løpet av 2021.

Gjennomsnittlig alder ved første uttak av alderspensjon var 65,4 år i 2019. For kvinner var gjennomsnittlig alder ved første uttak 66,0 år, og for menn 64,8 år.

Per juli 2019 var 48400 alderspensjonister bosatt i utlandet. I juli 2014 var antallet 38 700, noe som utgjør en vekst på 25 prosent på 5 år. Koronapandemien kan ha brakt enkelte endringer i denne situasjonen ved at pensjonister har valgt å flytte hjem.

Antallet minstepensjonister har gått ned med 9500 personer (6,4 prosent) fra juni 2018 til juni 2019. Ved utgangen av juni 2019 var antallet 138800 minstepensjonister. Hele 24,6 prosent av de kvinnelige alderspensjonistene var minstepensjonister i juni 2019. Blant menn var denne andelen kun 4,2 prosent.

\subsection{Regulering av grunnbeløpet og folketrygdens minsteytelser i 2020}

I forskrift 4. september $2020 \mathrm{nr} .1719$ om grunnbeløp, reguleringsfaktorer, satser for minste pensjonsnivå mv., gjeldende fra 1. mai 2020, framgår det at grunnbeløpet økte fra 99858 kroner (1. mai 2019) til 101351 kroner (1. mai 2020), dvs. en økning på 1,4 prosent. I forskriften ble det fastsatt virkningstidspunkt for regulering av kravet til minsteinntekt for rett til ytelser etter ftrl. kap. 4, 8, 9 og 14. Den mye omtalte reduksjonen på løpende pensjoner er som nevnt 0,75 prosent.

Minsteytelsene etter ftrl. $\S 19-8$ tredje til sjette ledd reguleres opp til følgende beløp:

- Lav sats etter tredje ledd fastsettes til 158621 kroner (fra 157171 kroner).

- Ordinær sats etter fjerde ledd fastsettes til 183587 kroner (fra 181908 kroner).

- Høy sats etter femte ledd fastsettes til 193188 kroner (fra 191422 kroner).

- Særskilt sats etter sjette ledd bokstav a fastsettes til 204690 kroner (fra 198 818).

- Særskilt sats etter sjette ledd bokstav b fastsettes til 300704 kroner (fra 297955 kroner).

\subsection{Stortinget avviste bedret pensjon for offentlig ansatte som arbeider etter 67 år}

Mye omtale ble viet et forslag fra Senterpartiet (Sp) - framsatt i Dok. 8: 141 L (2019-2020) om endringer i samordningsloven slik at personer som arbeider i det offentlige etter 67 år og 
mottar både lønn og pensjon, ikke får avkortet tjenestepensjonen slik situasjonen ble etter pensjonsreformen. Dette gjelder offentlig ansatte født i perioden 1944 til 1962.

Forslaget fikk ikke flertall ved Stortingets behandling, se Innst. 71 L (2020-2021).

\section{5. Økonomisk sosialhjelp}

\section{1 Økonomisk sosialhjelp}

Lovgrunnlaget er sosialtjenesteloven (lov om sosiale tjenester i NAV - stjl.) som forvaltes av NAV i kommunen.

Fra 2018 til $2019 \varnothing \mathrm{kte}$ antallet personer som fikk økonomisk sosialhjelp gjennom hele året, med 3 prosent. Av de 18000 personene som mottok stønaden gjennom hele året i 2019, var det om lag 8800 personer som også mottok sosialhjelp gjennom hele året i 2018.

De som har mottatt sosialhjelp sammenhengende i to år, skiller seg litt fra de resterende sosialhjelpsmottakerne. Både innvandrerandel og gjennomsnittsalder er høyere. Andelen innvandrere i gruppen som har mottatt sosialhjelp sammenhengende de to siste årene, er 63 prosent. Av innvandrerne utgjorde personer med landbakgrunn fra Somalia, Irak og Syria 46 prosent av dem som mottok støtte sammenhengende i 2018 og 2019.

Generelt er innvandrere overrepresentert blant dem som ikke har opptjente rettigheter i folketrygden, blant annet når det gjelder de helserelaterte ytelsene. Isolert sett kan dette føre til at en større andel av innvandrerbefolkningen mottar økonomisk sosialhjelp enn blant resten av befolkningen.

Den største gruppen sosialhjelpsmottakere er enslige uten barn. Nær 40 prosent av mottakerne av økonomisk sosialhjelp er enslige menn uten barn, mens 22 prosent er enslige kvinner uten barn. Videre forsørger 26 prosent av mottakerne barn under 18 år. Rundt 13 prosent av mottakerne er par uten barn. Disse andelene har vært ganske stabile over flere år.

Sosialhjelp var hovedinntekten til 41 prosent av mottakerne. En stor andel av sosialhjelpsmottakerne mottar økonomisk sosialhjelp som supplement til ytelser fra folketrygden. Om lag 26 prosent av mottakerne hadde trygd eller pensjon som hovedinntekt i 2018. Denne andelen har blitt redusert hvert år. Med bortfall av særlige trygdestønader til flyktninger (punkt 2.2.4) vil nok denne andelen fortsette å minske.

På tross av at antallet sosialhjelpsmottakere gikk ned, så gikk utbetalinger til sosialhjelp fra 2018 til 2019 opp med 0,4 prosent, til i underkant av 7 mrd. Dette henger trolig sammen med en nedgang blant dem som har mottatt sosialhjelp i en kortere periode, mens det har vært en $\emptyset$ kning blant dem som har mottatt hjelp i 8 måneder eller mer. Den gjennomsnittlige stønadstiden i 2019 var 5,5 måneder, en liten økning fra 5,4 måneder i 2018.

Antallet sosialhjelpsmottakere med barn har gått ned med 5 prosent. Det er første gang siden 2012 at dette tallet går ned.

Det blir spennende å se hvor stor betydning pandemien vil få for antallet sosialhjelpsmottakere i 2020.

\subsection{Plikt for kommunene til å stille krav om aktivitet og norskopplæring}

Stortinget har vedtatt en plikt for kommunene til å stille vilkår om aktivitet for mottakere av $\varnothing$ konomisk stønad etter sosialtjenesteloven, jf. Innst. 208 L (2014-2015). 
Regjeringen har i Granavolden-plattformen sagt at den vil stille krav om å delta i norskopplæring for mottakere av økonomisk sosialhjelp som på grunn av manglende norskferdigheter ikke blir selvhjulpne. På bakgrunn av dette sendte Arbeids- og sosialdepartementet (ASD) 9. september 2019 på høring forslag om endringer i aktivitetsplikten i sosialtjenesteloven for å bidra til at kommunen tar ansvar for å hjelpe og stille krav til mottakere av økonomisk sosialhjelp som trenger bedre norskkunnskaper for å komme i arbeid. Gjelder dette flyktninger med rett og plikt til å delta i introduksjonsprogram, skal det stilles slikt vilkår for rett til sosialstønad.

Dette ble lovfestet ved lov 18. desember 2020 nr. 142 og trådte i kraft 1. januar 2021.

\subsection{Stønadsnivået}

I motsetning til de siste års prosentuelle økning i folketrygdens pensjoner utover prisveksten har det bare skjedd en prisjustering av de veiledende sosialhjelpssatsene. Mange framhever at en vesentlig oppjustering av disse stønadssatsene vil være et målrettet tiltak i fattigdomsbekjempelsen.

Synspunktet om at en vesentlig $\varnothing \mathrm{kning}$ i satsene for $\varnothing$ konomisk sosialhjelp kan være et målrettet virkemiddel i fattigdomsbekjempelsen, er verken blitt delt av regjeringen Stoltenberg eller av regjeringen Solberg.

Dette avspeiles på nytt i ASDs rundskriv A-2/2020 Statlige veiledende retningslinjer for фkonomisk stфnad for 2021, datert 21. desember 2020. Det heter her: «Satsene i de veiledende retningslinjene prisjusteres i 2020 i tråd med anslaget for vekst i konsumprisene i nasjonalbudsjettet for 2019 (3,5 prosent).»

Tabellen nedenfor viser de veiledende retningslinjene for de ulike månedssatsene fra 1 . januar 2021. Satsene for 2021 er vist i venstre kolonne, mens satsene for 2020 er vist i høyre kolonne.

\begin{tabular}{|l|c|c|}
\hline \multicolumn{1}{|c|}{ Sivilstatus } & Satser for 2021 (kroner) & Satser fra 1.9.2020 (kroner) \\
\hline Enslige & 6450 & 6250 \\
\hline Ektepar/samboere & 10800 & 10450 \\
\hline Person i bofellesskap & 5400 & 5250 \\
\hline Barn 0-5 år & 2850 & 2750 \\
\hline Barn 6-10 år & 3250 & 3150 \\
\hline Barn 11-17 år & 4250 & 4100 \\
\hline
\end{tabular}

Av rundskrivet framgår at den veiledende satsen for økonomisk stønad til livsopphold i kategorien barn 0-5 år med virkning fra 1 . september 2020 ble $\varnothing \mathrm{kt}$ tilsvarende $\varnothing$ kningen i barnetrygden for barn inntil fylte 6 år. Så framholdes: «Ved utmåling av økonomisk stønad for enslige forsørgere med barn 0-5 år bør det også tas hensyn til at de mottar barnetrygd for 
ett barn mer enn de har forsørgeransvar for.» På hvilken måte dette skal hensyntas, framgår ikke.

De veiledende beløpene omfatter utgifter til det løpende, daglige livsopphold (grunnleggende behov), som for eksempel mat og drikke, klær og sko, husholdningsartikler og hygiene med mer, internett og telefon, fritidsaktiviteter, fritidsutstyr til barn, og reiseutgifter, som blant annet innbefatter bruk av offentlig kommunikasjon i forbindelse med daglige gjøremål.

Boutgifter, strøm og oppvarming, bolig- og innboforsikring og innbo og utstyr inngår i livsoppholdet, men er ikke inkludert ved fastsettelse av de veiledende stønadsbeløpene da dette er utgifter som varierer mye fra hushold til hushold og i ulike deler av landet. Stønad til dekning av denne typen utgifter må vurderes særskilt i hvert enkelt tilfelle.

Lovgrunnlaget for $\varnothing$ konomisk stønad finnes i sosialtjenesteloven (stjl.) $\S 18$ flg. Det er understreket i rundskriv A-2/2020 at økonomisk stønad er en skjønnsmessig ytelse, idet det også vises til ASDs rundskriv, Hovednummer 35 - 2012, punkt 4.18. Videre understrekes:
«Økonomisk stønad etter lov om sosiale tjenester i arbeids- og velferdsforvaltningen er en skjønnsmessig ytelse, jf. lovens $§ 18$ første ledd. De kommunale sosiale tjenestene i NAV-kontoret har både rett og plikt til å utøve skjønn når de vurderer om det skal ytes stønad, og ved utmåling av stønaden. Satsene i de veiledende retningslinjene må derfor betraktes som et veiledende utgangspunkt for det skjønn som skal utøves. Dersom stønadsbeløpet til arbeidsfør mottaker er på nivå med, eller over, hva mottakeren kan forventes å få gjennom arbeid, må det foretas en særskilt vurdering av nivået og krav til aktivitet. Det vises for øvrig til rundskriv, Hovednummer 35 - 2012 punkt 4.18.1.5 om forholdet mellom individuell behovsprøving, kommunale normer og statlige veiledende retningslinjer.»

Aktivitetsplikten er understreket ved følgende setning ovenfor: «Dersom stønadsbeløpet til arbeidsfør mottaker er på nivå med, eller over, hva mottakeren kan forventes å få gjennom arbeid, må det foretas en særskilt vurdering av nivået og krav til aktivitet.»

\subsection{Sosialtjenestemottakere og barnetrygd}

I mars 2019 ble barnetrygden $\varnothing \mathrm{kt}$ for alle barn fra 970 kroner til 1054 kroner. Videre $\varnothing \mathrm{kte}$ barnetrygden med 3600 kroner i året for barn opp til fylte seks år, med virkning fra 1 . september 2020. I statsbudsjettet for 2021 ble barnetrygden for barn opp til fylte seks år $\emptyset \mathrm{kt}$ med 300 kroner i måneden fra 1. september 2021. Det innebærer en ny årlig økning for disse barna på 3600 kroner, se punkt 6.3.

Det var tidligere opp til kommunene om de valgte å inkludere barnetrygd som en del av mottakers inntektsgrunnlag ved beregning av utbetaling av sosialhjelp. Mange av de fattigste familiene som er avhengige av sosialhjelp, fikk derfor ikke glede av økning i satsene for barnetrygd.

I statsbudsjettet for 2020 heter det vedrørende dette spørsmålet:

«Regjeringen foreslår å øke barnetrygden for alle barn opp til fylte seks år med 300 kroner i måneden fra 1. september 2020. Det utgjør 3600 kroner i året. Økningen vil forbedre alle småbarnsforeldres $\emptyset$ konomi, men vil bety mest for de med lav inntekt. Økningen skal også komme sosialhjelpsmottakere til gode.»

I forslagene fra Barne- og familiedepartementet (BFD) og ASD framgår at de statlige veiledende satsene for $\varnothing$ konomisk stønad til livsopphold for barn 0-5 år skulle $\emptyset$ kes tilsvarende fra samme tidspunkt. I praksis betyr det at de veiledende satsene for sosialstønad vil $\varnothing$ kes tilsvarende for de barna som utløser $\varnothing \mathrm{kt}$ barnetrygd.

Det samme er varslet for stønadsøkningen i 2021, dvs. det kan forventes en $\varnothing \mathrm{kning}$ i stønadssatsen for barn 0-5 år fra 1. september 2021 med 300 kroner per måned. 


\section{Stønadsvinnerne ved budsjettforlik de siste år}

\subsection{Innledning}

Det var stor forskjell på budsjettforhandlingene i 2019 da Solberg-regjeringen var en flertallsregjering med minimale endringer, til nå-situasjonen med en mindretallsregjering. Det måtte mange runder til med budsjettforhandlinger mellom regjeringspartiene og FrP før stortingsflertallet kunne samle seg om et omforent budsjett med mange typer påplussinger, hvorav de viktigste på velferdsområdet skjedde på pensjonsfeltet, se punkt 4 , og ved reduksjon i pasienters egenandelstak, se punkt 2.3.4.

\subsection{Minsteytelse og foreldrepenger ved fødsel, og om studentforeldre}

\subsubsection{Minsteytelsen ved fødsel og adopsjon}

Dersom vilkårene for rett til løpende foreldrepenger ikke er oppfylt, har mor, eventuelt adoptivmor, krav på en engangsstønad ved fødsel eller adopsjon, se ftrl. § 14-17. Det ytes engangsstønad for hvert barn som fødes eller adopteres. Denne engangsstønaden har mor rett til uansett om far, eventuelt adoptivfar, har selvstendig rett til foreldrepenger.

Engangsstønaden lå i mange år på $35263 \mathrm{kr}$ per barn født eller adoptert. I løpet av fem års budsjettforlik med $\mathrm{KrF} \varnothing \mathrm{kte}$ beløpet til $63140 \mathrm{kr}$ per barn fra 1. januar 2018. I budsjettforliket for 2019 ble beløpet hevet med ytterligere 20000 til 83140 kroner.

For 2020 skjedde «bare» en prisjustering idet beløpet ble hevet til $84720 \mathrm{kr}$ per barn, dvs. en $\varnothing$ kning på 1,9 prosent. Beløpet er uavhengig av om mottakeren mottar annen underst $\varnothing t t e l s e$ fra folketrygden, så som arbeidsavklaringspenger, overgangsstønad og uførepensjon.

Fra 1. januar $2021 \varnothing$ ker stønaden fra 84720 kroner til 90300 kroner. Denne store $\varnothing$ kningen fører til at regjeringen nærmer seg Granavolden-plattformens mål om å øke engangsstønaden til 1G. Økningen har altså vært på nær 160 prosent i løpet av 8 år av et tidligere «frosset» beløp.

Tidligere kunne stønadsmottakeren være berettiget til «mellomlegget» mellom løpende foreldrepenger og engangsstønaden som en kontantutbetaling. Dette er nå ikke mulig siden regelen som kan gi kombinert utbetaling av foreldrepenger og engangsstønad, er opphevd.

Engangsstønad ved fødsel er hva en kvinnelig student vil motta fra folketrygden ved fødsel om hun ikke har hatt inntekt som ville gi et høyere beløp i løpende foreldrepenger. I tillegg er det gitt egne regler for studenter med barn, se punkt 6.2.3.

\subsubsection{Foreldrepengeordningen - minimale endringer i 2020}

Fedre- og mødrekvotene ble ved endringslov 15. juni 2018 nr. $33 \emptyset \mathrm{kt}$ fra 10 til 15 uker fra 1. juli 2018. Dette reduserte samtidig ukene til fri fordeling mellom mor og far til 16 uker, slik at løsningen kommer nær en politisk målsetting om en tredeling av foreldrepengeperioden. Forarbeidene er Prop. 74 L (2017-2018) og Innst. 340 L (2017-2018). Dette gjelder ved uttak med 100 prosent dekningsgrad.

Ved 80 prosent dekningsgrad ble kvotene $\varnothing \mathrm{kt}$ med virkning fra 1. januar 2019 til 19 uker, med virkning for foreldre som startet stønadsperioden 1. januar 2019 eller senere. Den totale stønadsperioden med foreldrepenger er ikke endret, slik at det da blir 18 uker til fri fordeling.

Empiriske undersøkelser viser at far stort sett tar ut den lovbestemte «kvoten», mens mor tar ut sin kvote og stort sett den felles kvoten til fordeling. Dette innebærer at $\varnothing \mathrm{kning}$ av 
fedrekvoten fører til en økning i det antallet dager far er hjemme med omsorg for barnet. Videre er det et $\varnothing$ kende antall som tar ut foreldrepenger med 100 prosent dekningsgrad. Økningen har vært fra 33 prosent stønadsmottakere i 2009 til over 70 prosent i 2018.

Ved siden av disse $\varnothing$ kningene i kvotene ble det fra 1. juli 2018 foretatt en reell forlengelse av stønadsperioden ved tvilling- og trillingfødsel, gjennom endringer i § 14-9 fjerde ledd.

Fra 1. juli 2019 ble stønadsperioden utvidet ved fødsel av prematurt barn. Stønadsperioden blir forlenget i de tilfellene der fødselen skjer før utløpet av 32. svangerskapsuke, og da med det antallet uker og dager som går fra faktisk fødselsdato til beregnet termindato når fødselen skjer før svangerskapsuke 33. Disse ukene blir lagt til den ordinære stønadsperioden.

Forarbeidene er Prop. 73 L (2018-2019) og Innst. 318 L (2018-2019).

Eneste nye endring fra 2020 er at også ytelse i medhold av midlertidig lov om kompensasjonsytelse for selvstendig næringsdrivende og frilansere som har mistet inntekt som følge av utbrudd av covid-19, kan regnes med i inntektsgrunnlaget for foreldrepenger, se ftrl. § 14-6 tredje ledd bokstav f. Bestemmelsen er vedtatt opphevd per 1. januar 2021.

Som nevnt i punkt 3 er det sendt på høring forslag om regelendringer som hindrer «fedrefellen» ved at fedre kan miste rett til foreldrepenger (inkludert fedrekvoten) om de ikke melder uttakstidspunktet til NAV. Høringsutkastets hovedinnhold (høringsfrist 22. desember) er at uttak av foreldrepenger kan utsettes og tilpasses familiens livssituasjon, slik at den tidligere bestemmelsen om sammenhengende uttak bortfaller.

\subsubsection{Noe mer om studenter med barn}

I statsbudsjettet fra Kunnskapsdepartementet (KD) understrekes flere parallelt virkende ordninger, ikke minst i Lånekassen, for å styrke $\emptyset$ konomien til studenter med barn. Det gis et tillegg i livsoppholdsstøtten på 1750 kroner per måned per barn til studenter som forsørger barn under 16 år. Ved flere enn 2 barn er satsen 1139 kroner per måned for barn nr. 3 mv. Tilleggsstøtten blir gitt som stipend, men stipendet er behovsprøvd og kan i ettertid bli omgjort til lån dersom inntekt eller formue er over visse grenser.

Dersom barn under tolv år blir langvarig sjuke, kan studentforeldre òg ha rett til å få hele støttebeløpet for en periode på opptil fire og en halv måned omgjort til stipend.

Nybakte studentforeldre nyter godt av en foreldrestipendordning som på sett og vis speiler foreldrepengeordningen. Den innebærer at mor får hele støtten som stipend i en periode på inntil 49 uker. For far er perioden maksimalt 40 uker. Foreldrene kan ikke få foreldrestipend samtidig. Det er ingen krav om studieprogresjon i foreldrestipendperioden, fordi mor, ev. far, skal kunne bruke all disponibel tid på å være sammen med barnet. Foreldrestipendet er ikke behovsprøvd. Stipendet blir likevel til en viss grad samordnet med foreldrepenger ved at en forelder ikke kan få foreldrestipend dersom den andre forelderen samtidig får full foreldrepengeytelse fra NAV.

Nybakte studentforeldre er også unntatt fra de ordinære reglene om total støttetidsramme og stans i støtte ved forsinkelser i studieprogresjonen.

KD vurderte det derfor slik at de eksisterende ordningene for studenter med barn stort sett er tilfredsstillende. Personer i denne gruppen kan like fullt ha behov for livsoppholdsfinansiering utover det som tilbys i dag, og fra undervisningsåret 2020-21 gis tilbud om tilleggslån til studenter og elever over 18 år som forsørger barn under 16 år, finansiert som utdanningsst $\varnothing$ tte.

KD pekte også på at personer som får barn kort tid etter at de har fullført utdanninga, kan komme uheldig ut slik regelverket er innrettet i dag. De kan da verken ha rett til 
foreldrestipend fra Lånekassen eller ha opptjent rett til foreldrepenger fra NAV. Personer som får barn opptil sju måneder etter at de har avlagt en grad i høyere utdanning eller fagskoleutdanning, har rett til dette stipendet fra undervisningsåret 2020-21, finansiert som utdanningsst $\varnothing$ tte.

\subsection{Barnetrygden ble økt fra 2019 og øker på nytt for småbarn i 2021}

Barnetrygdens størrelse fastsettes hvert år av Stortinget i forbindelse med vedtaket av statsbudsjettet. Ordningen er lovfestet i lov 8. mars 2002 nr. 4 om barnetrygd.

I mange år ble satsene betraktet som høye, men de ble lenge liggende nominelt uendrede fra 1990-årene, og derved er den reelle verdien blitt kraftig redusert. I 2004 ble satsene justert noe ned samtidig som aldersrammen ble hevet fra 16 til 18 år. Det samme nominelle beløpet på $11640 \mathrm{kr}$ per barn per år ble vedtatt for 2018, for 12. året på rad. Beløpet var i statsbudsjettet for 2019 på nytt foreslått til $11640 \mathrm{kr}$ per barn per år, dvs. $970 \mathrm{kr}$ per måned.

Men stønadsbeløpet ligger ikke lenger fast. Barnetrygden ble, uavhengig av foreldrenes inntekt, økt til 12648 kroner per år med virkning fra 1. mars 2019. Økningen var del av budsjettforliket mellom regjeringen og $\mathrm{KrF}$.

Videre ble beløpet for barn under seks år økt med 300 kroner per måned, dvs. 3600 kroner på årsbasis.

Ved årsskiftet 2020/2021 er satsene:

- Ordinær barnetrygd til barn under seks år: 1354 kroner per måned; dvs. 16248 kroner per år

- Ordinær barnetrygd til barn fra seks år: 1054 kroner per måned; dvs. 12648 kroner per år

I statsbudsjettet for 2021 foreslo regjeringen, og fikk støtte i Stortinget, å øke barnetrygden til barn opp til fylte seks år med 300 kroner i måneden fra 1. september 2021. Det innebærer en årlig økning på 3600 kroner.

- Ordinær barnetrygd til barn under seks år vil da bli: 1654 kroner per måned, dvs. 19848 kroner per år.

Fra 2019 til 2021 har altså ordinær barnetrygd økt med snaue 9 prosent, mens for barn under seks år er økningen (etter justeringen fra september 2021) vel 70 prosent og utgjør en betydelig økning av et tidligere «fastfrosset» beløp.

Utvidet stønad til enslige forsørgere videreføres med 12648 kroner per år, dvs. beløpet for ett barn mer enn det vedkommende mottaker reelt forsørger.

Enslige forsørgere som fyller vilkårene for rett til utvidet stønad etter barnetrygdloven og med full overgangsstønad etter folketrygdloven og som har barn i alderen fra null til tre år, har også rett til et småbarnstillegg på $7920 \mathrm{kr}$ per år. Dette tillegget gjelder per enslig forsørger uavhengig av hvor mange barn i alderen 0-3 år vedkommende faktisk fors $\varnothing$ rger. Dette beløpet videreføres uendret.

Barnetrygden er skattefri og ikke behovsprøvd. Det har fra ulike hold vært luftet forslag om at barnetrygden bør behovsprøves, eventuelt regnes som skattbar inntekt hos mottakeren. Det har til nå vært en oppfatning om at dette lett kan gi vridningseffekter og økt byråkrati.

I tillegg vil en barnetrygd som gis til alle, ha en større allmenn oppslutning om et fortsatt høyt nivå. 
Barnetrygden er fremdeles en viktig overføringsordning fra alle skattytere til alle barnefamilier. Med de $\varnothing$ kningene som har skjedd for barn under 6 år, er dette blitt en særlig viktig ordning for fattige småbarnsfamilier.

\subsection{Andre stønader forbundet med svangerskap, fødsel og adopsjon; minstebidrag}

Fra én måned etter en fødsel får den som har omsorgen for barnet, rett til barnetrygd, se punkt 6.3. Om barnet ikke benytter barnehage med offentlig støtte, kan det gis kontantst $\varnothing t t e ~ i$ perioden barnet er mellom ett og to år, se punkt 7.3.

Ved adopsjon av barn fra utlandet har foreldrene rett til et engangsbeløp administrert av Bufdir. Hensikten med tilskuddet er å bidra til å styrke familiens økonomi knyttet til selve adopsjonen og motvirke en skjev sosial fordeling av adopsjoner. Det er et vilkår for stønad at adoptivforeldrene på forhånd har fått samtykke av norske adopsjonsmyndigheter til å adoptere barn fra utlandet. Gjennom budsjettforliket med $\mathrm{V}$ og $\mathrm{KrF}$ ble adopsjonsst $\varnothing$ tten for $2015 \varnothing \mathrm{kt}$ til $88370 \mathrm{kr}$, dvs. svarende til 1G, en veritabel økning (88 prosent) av en familierelatert stønad som ikke er lovfestet. Men stønadsordningen omfatter under et hundretalls familier idet antallet utenlandsadopsjoner har vært sterkt fallende de siste tiårene idet mange land forsøker å finne løsninger for barn i eget land.

Prinsippet er blitt videreført i etterfølgende år, dvs. at stønaden fra og med 1. januar 2021 $\varnothing$ kes fra 99858 til 101351 kroner, tilsvarende $\varnothing$ kningen i folketrygdens grunnbeløp, se punkt 4.2. Den nye satsen for støtten skal gjelde for adoptivbarn som kommer til Norge fra og med 1. januar 2021.

Dersom en kvinne føder hjemme, vil hun etter ftrl. § 5-13 ha rett til en kontantstønad ved hjemmefødsel. Beløpet lå i mange år på 1765 kr per barn, men ble fra 2015 kt til $2550 \mathrm{kr}$ per barn, en $\emptyset$ kning på vel 44 prosent. Deretter er beløpet $\varnothing \mathrm{kt}$ med rundt 3 prosent årlig. Beløpet er økt fra 2920 kroner i 2020 og til 3013 kroner i 2021, dvs. en økning på 3,2 prosent. Kravet framsettes overfor Helfo. Stønaden skal dekke merutgiftene ved hjemmefødsel.

Utgifter til jordmorhjelp ved fødsel utenfor institusjon dekkes også etter ftrl. § 5-12. Det er ikke vilkår om at jordmor har driftsavtale eller kommunal ansettelse for å få stønad. Det ytes også stønad til sekundærjordmor ved hjemmefødsel.

Fra fødselen av vil mor eller far med aleneomsorg for barn også ha rett til bidrag til omsorgen for barnet fra barnets andre forelder. Dersom vedkommende ikke er kjent, eller ikke kan eller vil betale, har enslig mor eller far krav på bidragsforskudd («minstebidrag») fra staten. Ordningen administreres av NAV. Dette bidragsforskuddet er forhøyet for personer med aleneomsorg og lav egen inntekt.

Satsene for bidragsforskudd prisjusteres hver 1. juli. Satsene fra 1. juli 2020 er henholdsvis $1670 \mathrm{kr}$ per måned for barn under 11 år og $2090 \mathrm{kr}$ for barn over 11 år (forh фyet forskudd), $1250 \mathrm{kr}$ uavhengig av barnets alder (ordincert forskudd) og $830 \mathrm{kr}$ uavhengig av barnets alder (redusert forskudd). Brutto årsinntekt mindre enn $297500 \mathrm{kr}$ gir rett til forhøyet forskudd. Ordinært forskudd gis ved inntekter over dette nivået, og til et tak avhengig av antallet barn. Ved årsinntekt over 534400 kr bortfaller retten til bidragsforskudd, uavhengig av barnetallet. 


\subsection{Barnehagelov, barnehagepolitikk og SFO - regelendringer, foreldrebetaling og gratis kjernetid}

\subsubsection{Viktige endringer i barnehageloven}

Fra 1. januar 2021 trådte en rekke endringer i ulike opplæringslover i kraft. Blant de viktigste endringene gjelder nye prinsipper og plikter for barnehageeierne i barnehageloven. Det er bare disse endringene som presenteres nedenfor; forarbeidene er Pop 96 L (2020-2021) og Innst. 302 L (2020-2021).

I fanebestemmelsen i barnehageloven (bhgl.) $\S 3$ om barns rett til medvirkning innføres en rett for barn «til å gi uttrykk for sitt syn i saker som gjeler dem selv». Videre lovfestes: «I alle handlinger og avgjørelser som gjelder barn i barnehagen, skal hva som er best for barnet, være et grunnleggende hensyn.»

I nyskrevet bhgl. $§ 7$ oppstilles generelle - og detaljerte - krav til barnehagens virksomhet, og i $\S 8$ detaljerte krav til vedtekter.

I bhgl. $§ 9$ oppstilles nye, strenge krav til internkontrollen i barnehagene, og denne skal dokumenteres.

For ytterligere informasjon vises det til forarbeidene.

\subsubsection{Foreldrebetaling i barnehager $m v$.}

Reglene for foreldrebetalingen for barns opphold i barnehage er regulert i betalingsforskriften (forskrift 16. desember 2005 nr. 1478). Beløpene fastsettes av Stortinget ved behandlingen av statsbudsjettet.

Fra 1. januar 2021 blir maksimalprisen på en barnehageplass 3230 kroner per måned og 35530 kroner per år, mens den i dag (dvs. fra 1. august 2020) er 3135 kroner per måned, dvs. en økning på 3,0 prosent.

For andre, tredje og flere barn videreføres dagens bestemmelser om minste søskenmoderasjon slik at prisen blir henholdsvis 70 og 50 prosent av foreldrebetalingen for første barn. Dette er regelfestet i betalingsforskriften $\S 3$ første ledd.

Det nasjonale minstekravet til redusert foreldrebetaling gjør at ingen familier må betale mer enn 6 prosent av samlet skattbar inntekt for en barnehageplass, med maksimalprisen som en $\emptyset$ vre grense, se betalingsforskriften $\S 3$ tredje ledd. Det betyr at alle husstander med samlet skattbar inntekt under ca. $550000 \mathrm{kr}$ vil ha rett til reduksjon i foreldrebetalingen per 1. januar 2020.

Inntektsgrensen for fritak for foreldrebetalingen i barnehage for 20 timer $\varnothing$ ker fra 566100 kroner per 1. januar 2021 til 583650 kroner per år fra 1. august 2021.

Ordningen med gratis kjernetid for tre-, fire- og femåringer fra familier med lav inntekt videreføres. Fors $\emptyset$ ket med gratis kjernetid i utvalgte områder er nå erstattet av en nasjonal ordning med gratis kjernetid for lavinntektsfamilier.

\subsubsection{Tak på SFO-betaling}

For første gang i 2020 ble kommunenes adgang til å innkreve foreldrebetaling ved opphold i skolefritidsordningen (SFO) nærmere regulert. Tidligere fantes ingen maksimalpris for SFO, en nasjonal rabattordning eller nasjonale krav til hvordan tilbudet skal organiseres. Forskning viser at det er store forskjeller i kvaliteten på SFO-tilbudet, og prisene foreldrene må betale, 
varierer fra 0 til nær 4000 kroner per barn per måned. Det er heller ikke gitt at de som har betalt mest, har fått det «beste» tilbudet. ${ }^{12}$

Det ble for 2020 bevilget 58 millioner kroner for å kunne innføre inntektsgradert foreldrebetaling i SFO på 1. og 2. trinn fra og med høsten 2020, og da med et tak på 6 prosent av husholdningens samlede personinntekt etter skatteloven kapittel 12 og skattepliktig kapitalinntekt.

Videre ble det gitt tilbud om gratis SFO for elever på 5. til 7. trinn med særskilte behov.

Høsten 2021 tar ny rammeplan for skolefritidsordningen (SFO) til å gjelde. Departementet vil fjerne $\varnothing$ konomiske barrierer som hindrer barn fra familier med lav inntekt fra å gå på SFO, og fra høsten 2021 utvides ordningen med inntektsgradert foreldrebetaling i SFO ved offentlige skoler til også å omfatte 3. og 4. trinn, slik at ordningen dermed gjelder 1. til 4. trinn. I tillegg opprettes en egen tilskuddsordning for SFO ved frittstående skoler som ønsker å tilby tilsvarende inntektsgradering i SFO for elever på 1. til 4. trinn. Videre vil utvalgte kommuner kunne tilby gratis SFO for familier med lav inntekt.

\subsubsection{Utvidelse av ordningen med fritidskort til dekning av barns utgifter til fritidsaktiviteter}

I statsbudsjettet $\varnothing \mathrm{kte}$ beløpet for 2021 til 120 millioner kroner til fortsatte fors $\varnothing \mathrm{k}$ med nasjonal fritidskort. Dette fritidskortet skal dekke utgifter til faste, organiserte fritidsaktiviteter for barn fra 6 til fylte18 år. I 2020 var dette beløpet 60 millioner kr. Målet med en slik ordning er at stadig flere barn og unge skal få delta i fritidsaktiviteter uavhengig av foreldrenes $\emptyset$ konomiske situasjon.

\section{Begrenset økning i flere familieytelser}

\subsection{Innledning}

Statsbudsjettet består av en rekke «faste» utgiftsposter med beløp som enten blir regulert ved endringer i folketrygdens grunnbeløp $(\mathrm{G})$, som alderspensjoner og overgangsstønader, eller ved at Stortinget fastsetter stønadssatsene ved behandlingen av statsbudsjettet. Enkelte av disse følger G-reguleringer, mens andre blir prisjustert eller «frosset».

Et fellestrekk for stønadsbeløp fastsatt for 2021 er at beløpene - i likhet med foregående år enten er prisjustert eller nominelt frosset, dvs. at de har fått en redusert verdi. Dette var i mange år tilfellet for barnetrygden, med dette er endret i årene etter 2019, se punkt 6.3.

I 2015 gjaldt slik «frysing» også for stønad til barnetilsyn, grunnstønad, hjelpestønad og utvidet hjelpestønad, mens beløpene senere er vekselsvis frosset eller prisjustert.

\subsection{Uendrede satser for grunnstønad, hjelpestønad, økte satser for utgifter til barnetilsyn i 2021}

Satsene for grunnstønad for dokumenterte ekstrautgifter ved uførhet med satser som er behovsavhengige, er for 2021 fastsatt med beløp fra $8232 \mathrm{kr}$ til $41052 \mathrm{kr}$ per år avhengig av dokumenterte behov, for hjelpestønad til uføre som må ha særskilt tilsyn og pleie, med $14748 \mathrm{kr}$ per år, og forhøyet hjelpestønad til uføre under 18 år som må ha særskilt tilsyn og

\footnotetext{
${ }^{12}$ Lek, laering og ikke-pedagogikk for alle. Nasjonal evaluering av skolefritidsordningen i Norge. Rapport 2018 fra NTNU og Stockholms universitet.
} 
pleie, med inntil 88488 kr per år. Dette er en ren videreføring av satsene som ble fastsatt for 2019.

Reglene for rett til grunnstønad og hjelpestønad står i ftrl. kap. 6.

Utgifter til barnetilsyn kan etter ftrl. $§ 15-10$ og $§ 17-9$ første ledd bokstav a gis til mor eller far med aleneomsorg for barn samt til etterlatte som er i arbeid. Stønad til barnetilsyn gis ved refusjon av 64 prosent av faktiske utgifter opptil de maksimalbeløp som fastsettes av Stortinget. Maksimalbeløpene fastsettes i tre satser: en sats for ett barn, en sats for to barn, og en sats for tre eller flere barn. Stønaden er skattefri. Stønaden faller helt bort når inntekten er over $6 \mathrm{G}$.

For 2021 ble det foretatt $\varnothing$ kninger for å møte forventet prisstigning, slik at utgifter refunderes med inntil $50340 \mathrm{kr}$ for ett barn, $65688 \mathrm{kr}$ for to barn og $74436 \mathrm{kr}$ for tre eller flere barn. Økningen fra 2020 til 2021 utgjør 3,5 prosent.

Behovsprøvd gravferdsstønad ble for 2021 prisjustert til 25377 kroner. Stønaden er skattefri. Stort sett må private bære kostnadene ved bisettelser når en person over 18 år dør. Det er i ftrl. kap. 7 oppstilt ulike vilkår for å kunne utløse rett til gravferdsstønad, avhengig av om avdøde var under eller over 18 år, og om avdøde over 18 år var enslig eller etterlot seg ektefelle, partner eller samboer.

\subsection{Kontantstøtten videreføres uendret i 2021}

Kontantstøtteordningen er lovfestet i kontantstøtteloven (lov 26. juni 1998 nr. 41). En mer detaljert utbetaling avhengig av timer i barnehage ble gjeninnført fra 1. august 2018, se endringslov 15. juni 2018 nr. 33.

For å ha rett til kontantstøtte må en nå ha fem års botid i Norge eller EØS-området.

Stønadsperioden for kontantstøtte er inntil 11 måneder fra og med måneden etter at barnet har fylt ett år, til og med måneden før barnet fyller to år (13 til 23 måneder).

Det gis full sats (7 $500 \mathrm{kr}$ per måned) dersom et offentlig støttet barnehagetilbud ikke benyttes, samt bestemte prosentsatser av dette beløpet ut fra oppholdstiden i slik barnehage. Mottakeren har rett til 80 prosent av full kontantstøtte (6 $000 \mathrm{kr}$ per måned) når det er avtalt oppholdstid i barnehage inntil 8 timer per uke, 60 prosent (4 $500 \mathrm{kr}$ per måned) ved oppholdstid fra og med 9 til og med 16 timer per uke, 40 prosent ( $3000 \mathrm{kr}$ per måned) ved oppholdstid fra 17 til 24 timer per uke, og 20 prosent (1 $500 \mathrm{kr}$ per måned) ved oppholdstid fra 25 til 32 timer per uke.

Det ytes ikke kontantstøtte hvis det er avtalt oppholdstid på 33 timer eller mer per uke.

Denne differensieringen har liten betydning idet tilnærmet alle barn (ca. 95 prosent) som det ble utbetalt kontantst $\varnothing$ tte for i september 2019, mottok full kontantst $\varnothing t t e$.

I mars 2020 ble det utbetalt kontantst $\varnothing$ tte for 30,1 prosent av barna i kontantst $\varnothing$ ttealder, noe som er 5,3 prosentpoeng lavere enn i 2013.

Det er vanligere å bruke kontantstøtteordningen i familier med innvandrerbakgrunn enn $\mathrm{i}$ familier uten innvandrerbakgrunn. Ordningen er mer brukt blant foreldre med lav utdanning og/eller lav inntekt.

Kontantstøtten er skattefri, se skatteloven $\S 5-43$ første ledd bokstav b. 


\section{Oppsummerende vurderinger}

Nær 111000 barn (11,3 prosent) bodde i 2018 i husholdninger med vedvarende lavinntekt, definert som en inntekt som over en periode på 3 år er lavere enn 60 prosent av medianinntekten (SSB 2020). Det er vel 5000 flere enn året før. Dette skyldes at flere innvandrerfamilier står utenfor arbeidslivet og at foreldrene har et lavere utdanningsnivå enn norske arbeidere og dermed lavere lønn. Innvandrere er også ofte lavere lønnet enn nordmenn, selv med høyere utdanning. ${ }^{13}$

Det er i byene påvist store geografiske forskjeller med opphopning av negative levekår i enkelte boområder, se den førnevnte NOU 2020: 16 Levekår i byer - Gode lokalsamfunn for alle.

Innskjerping av inngangsvilkårene for enkelte av trygdeordningene, som til enslig mor og far med aleneomsorg for barn, bidrar til barnefattigdom. ${ }^{14}$ Stønadsnivået på økonomisk sosialhjelp bidrar ikke til at familier passerer grensene for fattigdom. Men det hjelper med det økte stønadsnivået på barnetrygden og at denne økningen for småbarn (under 6 år) ikke skal influere på utmålingen av sosialhjelp.

I stedet for at utfordringen med barnefattigdom møtes med generelle overføringsordninger, er det utviklet særlige støtteordninger, herunder Nasjonal tilskuddsordning mot barnefattigdom. I statsbudsjettet for 2020 ble det satt av vel 310 millioner kroner for å motvirke eller dempe konsekvensene av fattigdom blant barn og ungdom. Ordningen skal bidra til at flere barn og ungdom kan få delta på viktige sosiale arenaer, som ferie- og fritidsaktiviteter, uavhengig av foreldrenes inntekt og sosiale situasjon. Denne ordningen styrkes i 2021 med 50 millioner.

Når generelle overføringsordninger som kunne styrket lavinntektsfamilienes $\varnothing$ konomi, fryses eller prisjusteres, føres flere barnefamilier inn i fattigdom. Det er dette som avspeiles i statistikken. Pensjonsytelsene er derimot - som vist i punkt 4 - blitt styrket de siste årene, slik at færre eldre nå befinner seg under fattigdomsgrensen.

Mer varige, målrettede overføringer rettet spesielt mot fattige forsørgere kan man sikre et visst inntektsnivå. Men det er kontroversielt om dette er den mest hensiktsmessige tilnærmingen. Både Stoltenberg- og Solberg-regjeringene har lagt til grunn at deltaking i arbeidslivet er den viktigste veien ut av fattigdom. Derfor blir den uttalte politikken at arbeidslinja skal ha forrang. Det skal ikke føre til bedre familieøkonomi å være stønadsmottaker enn arbeidstaker. Det må derfor ikke være «enkle veier» inn i varig offentlig understøttelse.

Samtidig foretas stadig lovendringer på det familie- og velferdsrettslige området som ikke vekker verken sterke følelser eller store offentlige debatter.

Selv om det er store verbale kamper mellom regjeringen og opposisjonen, både vedrørende statsbudsjettet og i enkelte lovsaker, utgjør disse mindre krusninger i det store bildet. Det er stor grad av konsensus, eller brede enigheter, om utenrikspolitikken og forsvarspolitikken, og heller ikke for store avstander mellom «blokkene» i den økonomiske politikken og velferdsog familiepolitikken, selv om det tidvis kan høres slik ut.

Det er heller ikke grunn til å glemme at en stor del av lovgivningsarbeidet er sterkt preget av våre EØS-rettslige forpliktelser, som i 2019 og 2020 ikke synes å ha bli tatt tilstrekkelig på

\footnotetext{
${ }^{13}$ SSB, se https://forskning.no/innvandring-arbeid/2008/09/oftere-overkvalifisert.

${ }^{14}$ Aslak Syse og Ingunn Ikdahl: «Regelverket for stønader til mor eller far med aleneomsorg for barn fra 1. januar 2016», FAB nr. 4 for 2016, s. 333-359. Dette er også empirisk dokumentert, se Therese Dokken: «Småbarnsmødre over på andre trygdeytelser etter innstramminger i overgangsstønaden», Arbeid og velferd nr. 3 for 2018.
} 
alvor, verken i lovgivningsarbeidet eller ved rettanvendelsen. Heller ikke på barnevernområdet synes de internasjonale rettskildene å ha blitt tillagt tilstrekkelig vekt. ${ }^{15}$

Det går mot et svært spennende nytt år med sterke politiske og rettslige utfordringer. Et spennende spørsmål blir om Solberg-regjeringen overlever valget i 2021, og eventuelt hvilke konsekvenser et regjeringsskifte vil kunne få på de politikkområdene som ligger innenfor FABs kjerneområder.

${ }^{15}$ Se Ingunn Ikdahl: «Rettssikkerhet i velferdsstaten» (leder), FAB nr. 1 for 2020, s. 3-6. 